\title{
UN NOVO TEXTO DRAMÁTICO DO CURA DE FRUÍME
}

\section{Damián Suárez Vázquez}

IES Santa Irene (Vigo)

Ramón Mariño Paz

Instituto da Lingua Galega,

Universidade de Santiago de Compostela

DOI: $10.17075 / \mathrm{cbfc} .2020 .009$ 



\section{INTRODUCIÓN}

A obra que presentamos foi composta por Diego Antonio Cernadas y Castro (1702-1777), o famoso Cura de Fruíme, e consérvase no Arquivo da Real Academia Galega (ms. 184-31-5). O seu título completo é Loa / para la fiesta de los Dolores de la Soleldad de Fruime, representada por el Sacris/tan y Criados del S[eñ]or Cura, advirtiendo / son ciertas la mañuelas que mútuamente / se imputan ${ }^{1}$. Trátase dunha peza dramática breve que se representou na romaría da Virxe das Dores de Fruíme (Lousame, A Coruña) xa cara ao final da vida do seu autor (o domingo 17 de setembro de 1775, segundo o noso cálculo). Esta obra, ademais de vir arrequecer a produción en galego de Cernadas, serve para poñermos en valor o seu labor como dramaturgo, hoxe practicamente esquecido, pero que no seu tempo debeu de gozar dun éxito considerable, especialmente entre as clases máis populares.

Súmase o achado desta $L F D$ a outros que se veñen producindo de maneira intermitente nos últimos anos e que están a debuxar un panorama da literatura galega da Idade Moderna algo máis rico e algo máis complexo do que comunmente se viña considerando, sobre todo no que respecta ao século XviII, e particularmente no que ten que ver co teatro. Entre as descubertas máis recentes cabe mencionar as doutros dous textos dramáticos setecentistas: a do Entremés ao feliz e real parto da nosa raiña de 1707 (Gondomar 2017), debida a Julio Ignacio González Montañés ${ }^{2}$, e a do Entremés gallego de Susana y Lorenzo, texto bilingüe de mediados do xviII, de próxima publicación ${ }^{3}$.

1 De agora en diante referirémonos de maneira simplificada a este texto como $L F D$.

2 A peza foi anunciada en novembro de 2017 no marco do simposio anual organizado polo Instituto da Lingua Galega que dá orixe a este libro. Na recuperación do noso patrimonio literario dramático resulta esencial o labor que desde hai anos realiza González Montañés a través do portal Teatro y espectáculos públicos en Galicia. De los orígenes a 1750 (2002-2009).

3 A noticia desta obra, que foi adquirida en outubro de 2016 nunha plataforma de vendas en Internet, debémoslla a Ernesto González Seoane. 
As que acabamos de mencionar e algunhas outras obras máis confirman definitivamente a existencia dun teatro breve de carácter popular producido en Galicia durante os Séculos Escuros ao que a lingua galega non foi allea ${ }^{4}$, tal e como se veu postulando desde a aparición en 1953 da Contenda dos labradores de Caldelas (1671). A este tipo de literatura en galego debe quedar vinculado desde agora o nome do Cura de Fruíme, cuxa produción dramática puido acadar un volume certamente destacado, como teremos ocasión de explicar neste traballo.

\section{O MANUSCRITO}

Está integrado por dez pregos de papel soltos organizados de maneira consecutiva e con numeración arábiga correlativa na marxe superior esquerda de cada un deles. Mide aproximadamente 15,5 por $21,9 \mathrm{~cm}$ e consérvase nunha carpeta de papel dobrado en que se pode ler o nome de "Fruíme $10^{0}$ " . A presentación do conxunto, que reúne en total catro pezas de Diego Cernadas, é coidada e apenas contén erros ou correccións. O tipo de letra corresponde ao século XIX e foi escrita por unha única man, que identificamos coa de Antonio María de la Iglesia (1819-1892). O manuscrito chegou á RAG despois de que o 1 de marzo de 1941 Eladia de la Iglesia formalizase a doazón dunha nutrida colección de papeis que pertenceran a seu pai Francisco e aos seus tíos Antonio e Benigno ${ }^{6}$. Desde 2016 é posible a súa consulta en lińa a través do Arquivo Dixital de Galicia 7 .

A copia do texto debeuse de realizar non moito antes do 14 de marzo de $1856^{\circ}$. Nesa data Antonio de la Iglesia daba inicio a unha relación epistolar co

4 Este teatro popular está composto por obras monolingües (como o Diálogo de Alberte e Bieito —ca. 1596- e o xa citado Entremés ao feliz e real parto da nosa raiña) e bilingües (como a LFD ou algunha outra peza conservada de Cernadas). Noutros casos a diversidade lingüística vén representada por idiolectos macarrónicos de clara intención paródica (así, no Entremés do portugués, 1710). Máis información sobre esta produción teatral atoparase en González Montańés (2002-2009).

5 O ordinal serve para diferenciar Diego Antonio Cernadas y Castro de Antonio Francisco de Castro (1746-1825), coñecido como "segundo Cura de Fruíme".

6 Véxase a "Historia arquivística" e a "Forma de ingreso" na RAG do arquivo dos Irmáns de la Iglesia en: https://arquivo.galiciana.gal/arpadweb/gl/consulta/registro.do?id=364496.

7 http://arquivo.galiciana.gal/arpadweb/es.ga.15030.arag/gl/catalogo_imagenes/grupo.do?registrardownlo ad=0\&path=53364\&config_rotacion=0\&posicion=15\&presentacion=pagina.

8 As marcas de auga localizadas nas follas do manuscrito apuntan, en calquera caso, á segunda metade do século xix. Pertencen á fábrica do empresario francés Pedro Molezún Lissarrague (1810-1898), instalada en San Xoán de Anceis, Cambre, "rebasada ya la primera mitad del siglo xIx" (Gayoso Carreira 1965: 
lexicógrafo e bibliotecario Francisco Javier Rodríguez (1797-1857) para informalo dun proxecto que tińa en marcha e para propońerlle o intercambio de composicións en galego, entre as que xa afirmaba posuír obras inéditas do Cura de Fruíme:

Tengo el pensamiento de publicar una Coleccion de poesías en gallego de todos los poetas antíguos y modernos que compusieron en este idioma, y aunque he reunido un buen número, acaso tenga V. las que á mí me faltan (Borrador de carta a FJR, 14.3.1856. RAG, cota 93-25).

Poseo ya muchas composiciones de Camino y Turnes. De Añon solo una [...]. He escrito á Orense, y todavia no me han contestado. De Pontevedra no dejarán de enviarme y son en mi poder ya tas foliadas todos los números del Gaiteiro. De D. Alfonso el Sabio tengo ya algo. Del Sr. Cura de Fruíme tambien se puede estraer de lo publicado y de lo inédito, tre to han dado que poseo (Borrador de carta a FJR, 25.3.1856. RAG, cota 93-34. As itálicas son nosas).

A $L F D$ aparece escrita nos pregos cos números 5 a 10 do manuscrito, enchendo en total vinte e dúas páxinas (as dúas páxinas finais do prego 10 están en branco). Ocupando os catro primeiros pregos atopamos, por esta orde, as seguintes pezas xa cońecidas do Cura de Fruíme: "Romance bilingüe" (s. d.), nos pregos 1 e 2 (do que a última páxina está en branco); "Adán non pudo pecar” (ca. 1753), nas tres primeiras páxinas do prego 3, e "Ilustrísimo Cabido" (ca. 1753), desde a terceira páxina do prego 3 ata a segunda do prego 4 (o resto do prego deixouse en branco). Non hai dúbida de que para copiar estes tres textos Antonio de la Iglesia se valeu do volume I do códice facticio que hoxe se conserva na Biblioteca Xeral da USC co título Décimas y Romances (Ms. 631).

Pero non son estas as únicas composicións de Cernadas compiladas polo escritor rexionalista. Entre os papeis doados por dona Eladia á RAG hai catro uni-

216). Esas marcas consisten no propio nome de "P. Molezun" en letras capitais (prego 8) e nas abreviaturas "H." (pregos 1, 3, 5, 7) e "T." (pregos 2, 4, 6, 10), acompañadas de filigranas con motivos vexetais. As datas extremas dos documentos en que se recollen esas mesmas marcas en diversos arquivos de Galicia son 1854 (Basanta Campos 2002: 508) e 1894 (519), o que non contradí a nosa proposta de datación inicial.

9 Para facer referencia aos diferentes textos de Diego Cernadas e a outras composicións en galego da Idade Moderna empregamos os títulos e as datacións propostos en Gondomar 2017. 
dades documentais máis integradas por diferentes textos en galego ou en galego e castelán. Son as seguintes:

1. Manuscrito 184-31-3. Composto por catro pregos soltos con numeración romana. Na súa materialidade (letra, tipo de papel e marcas de auga, tamaño e organización dos pregos) é idéntico ao manuscrito que contén a $L F D$. Recolle os seguintes textos: "Eu non pensei, meu Farruco" (a. 1775), que ocupa as tres primeiras páxinas do prego I; "Xa que sodes tres Xosés" (p. 1761), na terceira e cuarta páxinas do prego I; "A cabaza" (1775), nas dúas primeiras páxinas do prego II; "Paisanińos nobres" (1756), ao longo dos pregos III e IV (queda en branco a última páxina). Agás o poema titulado "A cabaza”, todos os demais foron extraídos do volume II do códice de Décimas y Romances da Biblioteca Xeral da USC (Ms. 631). Canto a "A cabaza", é posible que Antonio de la Iglesia copiase o manuscrito solto hoxe conservado no Museo de Pontevedra (Caixa 10-2 do fondo "Cabeza de León”), único testemuño setecentista que se coñece da composición. Os papeis de Cernadas y Castro do Museo de Pontevedra proceden do arquivo privado de Salvador Cabeza de León (1864-1934) (Pardo de Neyra 2002: 158); a procedencia dos papeis do manuscrito 631 da Biblioteca Xeral, adquiridos pola USC en febreiro de 1995, énos descoñecida ${ }^{10}$. Quizais todos estes materiais formasen parte, a mediados do século XIX, dunha mesma colección e, se así fose, pode que o seu propietario, cuxa identidade nos é descońecida, llos facilitase a Antonio de la Iglesia.

2. Manuscrito 184-31-4. Integrado por catro pregos soltos con numeración arábiga. Aínda que a caligrafía corresponde a Antonio de la Iglesia, o tipo de papel empregado é diferente (máis claro e de maior gramaxe) do dos manuscritos anteriores. Recolle as composicións en galego ou en galego e castelán das Obras en prosa y verso de Fruíme, mantendo a mesma orde de aparición ca os volumes impresos: "Ronca do río Miño" (1755), "Befa do río da Chanca" (1755), "Desengano ao pozo da Pinguela" (1755), "Verdusido, Verdusido" (ca. 1772), "Se pudera darche os tranchos" (s. d.) e "Brinde paisano" (1753), no primeiro prego; "Co desexo de acordarvos" (ca. 1773), no segundo prego e na primeira páxina do

\footnotetext{
${ }^{10}$ Non é correcta a identificación deses dous volumes da USC cos papeis editados na tese de licenciatura de María Rita Peinado López (cf. Pardo Gómez 1998: 125), naquel momento pertencentes ao crego Xesús Carro (1884-1973), quen os recibira de Cabeza de León (Peinado López 1972: 2), e hoxe en paradoiro descońecido.
} 
terceiro; "Ai do Allo, ai do Allo" (1752), "Vinde ver o dote" (s. d.), "Meu Carballo, tu estás cego" (1752), "Vós decís que cante, cante" (1759) e "Dizque xa vén por camiño" (1759), no terceiro prego e parte do cuarto; finalmente, o "Diálogo da lavandeira e o peregrino" $(1762)^{11}$, nas tres últimas páxinas do cuarto prego ${ }^{12}$.

3. Manuscrito 184-31-1. Consiste nunha única folla de papel reutilizado dun envío postal e recolle unha copia do poema "Se pudera darche os tranchos". O texto aparece modernizado segundo os criterios ortográficos de Antonio de la Iglesia e co título traducido ao galego; tamén se simplificou o contido dunha nota do orixinal. Esta versión do poema é a que amosa o "Mosaico poético" do Album de la caridad (Album 1862: 164).

4. Manuscrito 184-31-2. Trátase da última das tres follas que debeu de ter orixinalmente a peza, como se comproba pola numeración do papel. Contén a parte final (os 16 últimos versos) de "Co desexo de acordarvos". Coma no caso do manuscrito anterior, correspóndese coa versión do poema preparada para o "Mosaico poético" do Album de la caridad (Album 1862: 307-309).

Á vista destes datos, podemos afirmar que as composicións do Cura de Fruíme que Antonio de la Iglesia puido reunir procedían fundamentalmente de dúas fontes: das Obras en prosa y verso, publicadas postumamente en Madrid entre 1778 e 1781, e de unha ou quizais dúas coleccións de manuscritos de orixe privada, hoxe repartidas entre a Biblioteca Xeral da USC e o arquivo do Museo de Pontevedra. Esta compilación de textos en lingua galega (ou, nalgún caso, en galego e castelán) tiña por obxecto a preparación dunha Colección de poesías en gallego de diversas épocas, que lamentablemente non chegou a ver a luz. Porén, Antonio de la Iglesia aproveitou parte deses materiais para o seu "Mosaico poético", a nutrida escolma de textos engadida ao Album de la caridad (1862) ${ }^{13}$;

${ }^{11}$ Pasou ata agora desapercibida para os investigadores unha edición deste texto impresa en Madrid en 1762, é dicir, publicada con anterioridade ás Obras en prosa y verso e en vida do autor (Cernadas y Castro 1762: 91-128).

${ }^{12}$ Faltan neste manuscrito dous textos galegos das Obras en prosa y verso, quizais por descoido do copista: "Miña Virxe dos Dolores" (ca. 1773) (Obras III 1779: 305), en realidade tres coplas incrustadas nunha composición en castelán máis extensa, e "Morder ou andarse en chanzas" (1752) (Obras IV 1779: 193), versión en galego dun breve fragmento da Sátira $X V$ de Xuvenal.

${ }^{13}$ Como xa se dixo, foron as composicións "Se pudera darche os tranchos" (Obras I 1778: 331) e "Co desexo de acordarvos" (Obras III 1779: 314-318), ás que se engadiu un terceiro poema en castelán: "Mapa de Galicia en abreviatura" (Obras I 1778: 281-284; Album 1862: 269-270). É doado advertir que este "Mosaico poético" pouco tiña que ver co proxecto concibido orixinalmente por Antonio de la Iglesia, ben porque nel o galego perdía a exclusividade como lingua de creación poética, ben porque cronoloxicamente o 
pasados os anos, aínda publicou a antoloxía en tres volumes El idioma gallego. Su antigüedad y vida (1886), máis próxima ao seu proxecto orixinal ${ }^{14}$. Curiosamente, non aproveitou ningún dos inéditos de Cernadas y Castro para estes traballos.

Queda por cońecer a fonte empregada para copiar a $L F D$, que non aparece entre os papeis da USC nin entre os do Museo de Pontevedra. De feito, non estamos en condicións de poder afirmar tan sequera se se tratou realmente dun manuscrito ou se foi un texto impreso. Fose como fose, ao preparar a versión definitiva da $L F D$, Cernadas debeu de pensar nun destinatario de fóra de San Martiño de Fruíme, como suxiren as anotacións marxinais sobre a identidade de dúas persoas mencionadas (un estanqueiro e o capelán da parroquia).

\section{CONTIDO E FORMA}

Para comezar, convén facermos algunha aclaración sobre a adscrición xenérica do texto que nos ocupa. É sabido que a loa, cuxa orixe e desenvolvemento hai que situar no Século de Ouro español, estaba dotada dunha finalidade práctica, pois tratábase do xénero que presentaba e daba paso a unha comedia ou a un auto sacramental na festa teatral barroca. No século XVII, as principais funcións desta peza breve consistían en captar a atención do público e pedir o seu silencio, en preparalo para a obra que ía ver a continuación e en lograr a súa benevolencia, escusando posibles erros de interpretación dos actores ou as faltas que o autor puidese cometer na composición (Buezo / Plaza Carrero 2008: 85-86). Ademais, nestes primeiros anos adoitaba incluír unha loanza da calidade dos actores da compañía ou do mecenas, elemento que deu orixe ao nome do xénero. Mais o certo é que non encontramos nada disto na $L F D$, que presenta os formalismos propios do entremés (outro xénero breve imprescindible na festa teatral), entre os que podemos sinalar o seu ton burlesco e xocoso, a incorporación de canto e música, o final a paus, as alusións escatolóxicas ou o uso dunha linguaxe altamente expresiva a base de interxeccións, exclamacións e insultos. Hai que ter presente

corpus quedaba reducido ás obras procedentes de "nuestros vates gallegos contemporáneos". De maneira sorprendente, o volume deu cabida aos poemas de Diego Cernadas (o autor máis antigo da selección e o único falecido antes do século xIx), que de ningunha maneira podería ser percibido como unha figura contemporánea na altura de 1862.

${ }^{14}$ Neste caso recolleu os poemas "Meu Carballo, tu estás cego" (Iglesia 1886: 209-210; Obras V 1780: 72-73) e "Verdusido, Verdusido" (Iglesia 1886: 210-212; Obras I 1778: 322-323). 
que entre os xéneros breves do Século de Ouro español non foi nada rara esta clase de interferencias. De feito, xa desde século xvir se pode comprobar como a loa se foi contaxiando do entremés ou do baile na súa forma, na linguaxe e na escenografía empregada (Buezo / Plaza Carrero 2008: 86).

Ora ben, neste punto resulta inevitable preguntarnos por que a $L F D$ recibiu efectivamente a denominación de loa se, en realidade, só presenta as características formais e de contido dun entremés. Á falta dunha resposta concluínte, cabería considerar que puido ser a primeira peza representada dentro dun pequeno grupo de obras, e que por tanto a denominación lle vińese imposta pola súa posición de inicio, non por ter realmente unha función prologal. Sabemos que noutra loa de Cernadas, tamén pertencente ás representacións da romaría da Virxe de Fruíme, dous personaxes dan paso a un entremés na súa parte final (véxase o apartado 5).

Canto ao seu contido, a $L F D$ está composta por un único acto dividido en tres escenas (de 228, 123 e 166 versos, respectivamente) ${ }^{15}$ e nela interveñen seis personaxes en distinta proporción. Na primeira escena asistimos ao encontro de Xerpe (criado de Diego Cernadas) e Carlos de Andrade (o sancristán), cando este regresaba á súa aldea. Os dous personaxes manteñen unha longa conversa que xira fundamentalmente arredor da común afección polo tabaco (con acusacións mutuas de furtárenllelo a Cernadas e a don Francisco, o capelán) e do estado de saúde de Carlos, aflixido por varias doenzas e por unha sede insaciable que o leva a beber ás agachadas o viño do cura. Remata a escena cando os personaxes senten unha foliada que se aproxima e deciden esconderse para ver de quen se trata. $\mathrm{Na}$ segunda escena, bastante máis breve, presenciamos varios romeiros que cantan coplas alusivas á Virxe (e tamén ao capelán, ao cura e ao sancristán de Fruíme). Trátase do grupo formado por Pepe, Ciprián, Tereixa e Catuxa, que fan un alto para a merenda. Mentres comen e beben, arrancan a falar sobre o cura (sobre o aspecto avellentado que presenta, sobre os cartos de que podería dispońer ou so-

${ }^{15}$ No tránsito da primeira á segunda escena hai dous personaxes que se esconden e, aínda que na $L F D$ non se indica que saian do escenario, tampouco se aclara que se oculten detrás de calquera obxecto. A maneira en que se anuncia o seu regreso ás táboas ("Salen Carlos y Xerpe", despois do v. 351) é idéntica á empregada no inicio da segunda escena para anunciar a incorporación doutros personaxes ("Salen Pepe, Ciprián, Teresa", despois do v. 228), polo que interpretamos que efectivamente se produciu unha saída e posterior entrada no escenario dos dous personaxes e, por conseguinte, falaremos de dous cambios de escena na obra. 
bre as ganancias que obtivo pola venda dunha mula), contrapoñéndoo coa figura do capelán. Acaban bebendo e invocando a Virxe. Xa na última escena, saen de novo Carlos e Xerpe, que saúdan o grupo e son convidados a comer e beber. Un dos romeiros, Ciprián, interésase pola identidade de Carlos, que lle é desvelada por Xerpe. O romeiro lembra entón que anos atrás lle escoitara cantar varias coplas dedicadas á Virxe, que agora lle pide que repita. Carlos accede e todos celebran a actuación ${ }^{16}$. Finalmente, os romeiros tocan e bailan unha muiñeira e teiman en que Carlos participe na diversión, mais este négase e responde con paus. Remata a peza cunha nova invocación á Virxe.

A $L F D$ segue a tendencia imperante no xénero ao empregar o romance como forma métrica (Buezo / Plaza Carrero 2008: 84), neste caso octosílabo e con rima $-e-a^{17}$. Os versos 248 e 249 , con rimas consecutivas, presentan unha anomalía orixinada talvez por un problema de copia, aparentemente pola falta de un verso. Con todo, no fragmento non se detectan problemas de contido ou de sintaxe:

Pepe. Ora ben, este parece bo canto para a merenda.

Ciprian. Tamen mo parece a min.

Teresa. E pois logo pouso a cesta.

Pepe. Si; que o dia non da espera. (Siéntanse.) ¿E el vén algo que digamos? (vs. 245-250)

No que concirne á métrica, aínda aparece unha segunda anomalía xa cara ao final da obra, cando no transcurso dunha intervención de Carlos de Andrade se intercala un verso trisílabo (coa queixa dos personaxes, golpeados polo sancristán nun lance cómico). Este verso, que sobre o escenario tería que recitarse de modo simultáneo á intervención do sancristán e, por tanto, sen que esta se vise interrompida (como pide a estrutura sintáctica encabalgada dos versos 507 e 509), forma en principio parte do esquema de rimas, ao tratarse dun verso solto situado entre dous versos que riman entre si:

${ }^{16} \mathrm{O}$ texto desas coplas non aparece recollido no manuscrito.

${ }^{17}$ Apártanse deste esquema as catro coplas cantadas polo grupo de romeiros no inicio da segunda escena (vs. 229-244), con rimas independentes. 
Carl. Qué haceis maldita caterva

de demonios? esto es ya

muchísima desvergüenza (dale á todos depalos.)

Todos. Ay! Ay!

Carl. conmigo! bellacos, fuera (vs. 505-509).

A distorsión métrica que introduce o verso 508 talvez sexa só aparente, se consideramos que se debe repetir a interxección ata completar a súa medida, isto é, que apareza sete veces para formar o octosílabo preceptivo.

Noutra orde de cousas, compróbase que un dos personaxes (Carlos de Andrade) se expresa en castelán, o que permite definir a $L F D$ como unha obra bilingüe. Poderemos ver ademais que o personaxe ten unha participación destacada nos diálogos, polo que a porcentaxe de discurso que abrangue finalmente a lingua por el empregada é elevada: suma 188 versos completos e seis medios versos, o que supón un $36,9 \%$ do total da obra.

Tamén aparecen redactados en castelán o título e as didascalias, como é norma nos textos dramáticos cońecidos da Idade Moderna. Incluso algúns dos nomes dos personaxes adquiren a forma da lingua do mundo oficial nas rúbricas escénicas, fronte ao que acontece nos diálogos. Así, Teresa e Catalina son as solucións preferidas nas anotacións do dramaturgo, mentres que Tereixa (vs. 261, 338, 477) e Catuxa (v. 347) se rexistran no discurso dos personaxes ${ }^{18}$; de maneira contraria, non se castelaniza o nome de Xerpe, que se mantén inalterado ao longo de todo o texto ${ }^{19}$. Como curiosidade, cabe apuntar que os personaxes galegofalantes utilizan sempre a variante Calros $^{20}$ para o nome do sancristán (vs. 1, 61, 119,

\footnotetext{
${ }^{18}$ No repertorio inicial de "Interlocutores" tamén atopamos a forma Catuxa, e non Catalina.

${ }^{19}$ Seguindo a opinión de Ana Isabel Boullón, a quen agradecemos a información facilitada, o máis probable é que a forma Xerpe se corresponda co apelido do personaxe (cf. CAG, s. v. Gerpe). Segundo os datos do Dicionario dos Apelidos Galegos (DAG, en preparación), Xerpe é característico do concello de Santa Comba e ten orixe no topónimo de Dumbría (na parroquia de Salgueiros), o que casa ben coa localización do texto. As atestacións máis antigas do apelido coa consoante inicial palatalizada son do século XVI, mentres que os testemuños medievais aparecen sempre con $<S->$. Opina Ana Boullón que é dubidoso que esteamos ante un alcume, dado que a forma palatalizada do substantivo non parece estar viva no territorio (polo menos non se recolle no TILG (http://ilg.usc.es/TILG/) nin no DdD (http://sli.uvigo.es/ddd/ index.php). Indícanos finalmente esta investigadora que non dispón de rexistros en que Xerpe funcione como hipocorístico.

${ }^{20}$ Esta variante metatizada deste nome debeu de ter certa circulación desde a Idade Media, pois nos Miragres de Santiago aparece ata en 104 ocasións, coas variantes gráficas Calrros e Calros (cf. TMILG).
} 
223, 438...), fronte á forma canónica que usa Diego Cernadas (a través da voz do sancristán; cf. mi Carlitos, no v. 173).

A $L F D$ contén datos de interese que permiten relacionar o texto con outros escritos do Cura de Fruíme e mesmo fixar con bastantes garantías a súa datación. En relación con isto último, resulta esencial a seguinte pasaxe da segunda escena en que dous dos romeiros se refiren a Diego Cernadas:

Teres. Bravo lagarto pareces!

¿e cantos anos ja leva

o cura no beneficio?

Cipr. Oin decir que corenta e catro justińos (vs. 304-308).

Grazas á documentación conservada sabemos que Cernadas y Castro foi nomeado párroco titular de San Martińo de Fruíme o 6 de xullo de 1731, "tras de aproba-lo concurso a parroquias celebrado probablemente arredor de maio-xuño do ano 1731" (García Cortés 2002: 88) ${ }^{21}$. Deste modo, é doado calcular que a redacción do texto corresponde ao ano 1775 , sempre que as contas do autor estivesen ben botadas. A composición da $L F D$ sitúase, xa que logo, no tramo final da súa existencia, cando tińa 73 anos e apenas lle restaban dezaoito meses de vida (faleceu o 30 de marzo de 1777). A descrición que os romeiros fan do personaxe na segunda escena é ben elocuente:

Pepe. ¿E a vos que vos pareceu do Crego de Fruime?

$$
\begin{aligned}
& \text { Cip. Afellas } \\
& \text { que alá cando mozo habia } \\
& \text { de ter boa parecencia; } \\
& \text { mais hoje parece ja } \\
& \text { un cañoto da devesa. }
\end{aligned}
$$

${ }^{21}$ Mais o certo é que aínda tardou algúns meses en poder incorporarse de facto ao beneficio, porque previamente tińa que recibir as ordes maiores (fíxoo na cidade de Betanzos entre o 22 e o 26 de decembro de 1731, en tres cerimonias oficiadas polo arcebispo Yermo Santibáñez). Ata entón as funcións litúrxicas de Fruíme foron celebradas polo presbítero Francisco Prieto Romero (o capelán "don Francisco" mencionado na $L F D$, nos versos $89,233-240$ e 284-303), nomeado vicecura para o efecto. A primeira acta sacramental asinada na parroquia de Fruíme por Cernadas é a dun matrimonio celebrado o 23 de abril de 1732 (García Cortés 2002: 88-93). 
Teres. Malpocado! mais con todo

se non fose por aquela

falta de todos os dentes,

e moas, ainda pudera

ir pasando entre os mais guapos

curas de toda esta terra,

porque a fachada he bizarra.

Pepe. Cala, muller, que en concencia

ja vay todo deslombado,

e non rege jaacabeza (vs. 266-281).

Esta pasaxe, de manifesta intención humorística, serviríanos igualmente para datar de maneira aproximada o texto se non contásemos coa indicación do tempo transcorrido no beneficio, pois as mencións que fai Cernadas da súa propia decrepitude física pertencen necesariamente á súa produción tardía; así, por exemplo, a referencia á falta de dentes e moas só se documenta noutros textos do autor a partir de 1766 (Fernández Salgado 2017: 85).

\section{CARLOS DE ANDRADE}

Ademais de ser o personaxe con maior protagonismo na $L F D$, cómpre aclarar que o sancristán Carlos de Andrade foi unha persoa que existiu realmente. Grazas á localización da súa partida de defunción ${ }^{22}$, sabemos que faleceu o 30 de marzo de 1779, dous anos despois de Cernadas, e que do mesmo xeito foi soterrado na capela da Virxe das Dores da igrexa parroquial de San Martiño. Cuestión á parte é se o seu nome foi utilizado como pseudónimo polo Cura de Fruíme en diversos impresos, como interpretaron algúns dos seus contemporáneos ${ }^{23}$ e como acepta a crítica actual, ou se debemos considerar que realmente o sancristán foi o

22 Poden consultarse a transcrición e a reprodución fotográfica do documento no "Anexo" final do traballo. A acta de defunción de Carlos de Andrade foi localizada no Arquivo Histórico Diocesano de Santiago de Compostela por Anxo Rodríguez Lemos, a quen agradecemos a súa colaboración.

${ }^{23}$ Por exemplo, o autor anónimo das Décimas contra Diego Cernadas (ca. 1770), cando afirma: "Dibulgas ti Cantinelas / co nome do Sacristan, / ben se saue que seran / de quen despauila as Velas: / fas Decimas con Cautelas / como que he Carlos con fraudes" (Fernández Salgado 2017: 44); e talvez os compiladores das Obras en prosa y verso póstumas, onde se inclúen os petitorios asinados polo Sacris, Proto-Sacris ou Sacristan de Fruime (aínda que tamén se recollen outras pezas non debidas a Cernadas). 
autor material das composicións por el asinadas (fundamentalmente os romances iniciais dos petitorios das décadas de 1760 e 1770, ademais dalgúns textos en prosa), ou polo menos dunha parte desas composicións. Cremos que se trata dunha cuestión non exenta de dificultade e que esixe un estudo demorado por parte da crítica especializada. O que está claro é que o petitorio de 1779, asinado por "El Sacristan de Fruime" e titulado Quien possee no pleytee, onde se repiten os tópicos dos petitorios anteriores, non puido ser redactado por Diego Cernadas, xa non porque fose publicado case dous anos despois da data do seu falecemento, senón porque nos versos do "Romance" inicial aparece referida a circunstancia do deceso ${ }^{24}$ :

Que hasta aqui no os disgustassen

mis suplicas, pienso que era,

porque al fin las sazonaba

de mi Cura la Eloquencia ${ }^{25}$.

Mas despues que de mi Musa

espiró con el la fuerza,

y se apagó con su vida

el sacro ardor de mi vena (Sacristan de Fruime 1779: 2) ${ }^{26}$.

Outro tanto podería dicirse, aparentemente, do petitorio publicado un ano antes, o primeiro aparecido tras a morte de Cernadas $^{27}$ e que leva por título $E l$ Sacristan de Fruime, a quien el sentimiento por la muerte de su amado Cura desecó aquel buen humor, que solia gestar en sus coplas, llora sus desamparos... (García

${ }^{24}$ Reproducimos con fidelidade o texto impreso, substituíndo unicamente os eses longos de inicio ou interior de palabra $(<\lceil>)$ por eses curtos ou redondos $(<s>)$.

${ }^{25}$ En efecto, os distintos petitorios do sancristán conteñen habitualmente na parte final algunha composición - moitas veces xogos de habilidade versificadora - atribuída sobre o papel a Diego Cernadas.

${ }^{26}$ Ademais, nese mesmo petitorio, o autor deféndese dos que o acusaban de publicar co seu nome escritos de Diego Cernadas: "Otros dijeron que yo, / para salir à la questa, / hize en la alforja del Cura / difunto la providencia. / Este falso testimonio / lo sentí sobre manera, / que el tratarme de Ladron, / quien no vé que es una afrenta? / Y à mi me disuena mucho, / porque nunca en mi conciencia, / por lucir, pude ajustarme / à vestir de ropa agena. / Assi mis pobres conceptos, / hijos de mi pobre idéa, / los pongo en la calle como / los parió su Madre mesma. / Van desnudos, van sin gala, / pero al fin van sin fachenda, / y assi pueden parecer / con la cara descubierta" (Sacristan de Fruime 1779: 3).

${ }^{27}$ Os petitorios para o culto da Virxe das Dores publicábanse anualmente pola festa da Candeloria (Fernández Salgado 2017: 41), que se celebra o 2 de febreiro; de aí que o derradeiro impreso saído en vida de Cernadas fose o de 1777. 
Cortés 2002: 190, nota 244). Lamentablemente é un impreso que non demos localizado ata o de agora ${ }^{28}$.

Nos petitorios asinados polo sancristán atopamos referencias de tipo persoal que, de non estaren falseadas, permiten esbozar unha biografía do personaxe. Así, pois, sabemos que Carlos Antonio de Andrade naceu a finais do século XviI ${ }^{29} \mathrm{e}$ que, malia contar con ascendencia fidalga por lińa paterna, non acadou título de nobreza, dada a condición de sacerdote do seu proxenitor ${ }^{30}$. Recibiu formación humanística no colexio da Compañía de Xesús de Monforte, sen chegar a completar estudos superiores (Obras VI 1780: 307), e alí traballou como axudante da Escola de ler ata que abandonou o centro por causas descońecidas ${ }^{31}$. Co paso do tempo acadou o título de Notario apostólico ${ }^{32}$. Ignoramos en que momento e por que motivo se instalou na parroquia de San Martińo de Fruíme, onde exerceu de mestre de escola (tamén nas parroquias vecińas de Lesende e Lousame) (Obras VI 1780: 231), ademais de levar a cabo o exercicio do notariado ${ }^{33}$. Non consta que tivese descendencia do seu matrimonio con Francisca da Figueira ${ }^{34}$, da que quedou viúvo en data ignorada. A situación de precariedade ou pobreza

${ }^{28}$ Despois de 1779, tras a morte de Carlos de Andrade, publicáronse polo menos dous petitorios máis, un en 1780 e outro en 1782. Aparecen asinados polo "Vice-Sacristan Antonio de Zes, alías el Longo" e neles xa se anuncia a vacante da sancristía de Fruíme (García Cortés 2002: 191-193). Hai quen considera que o autor dos petitorios publicados despois de 1777 foi Antonio Francisco de Castro (1746-1825), o segundo Cura de Fruíme (Rey Castelao 1998: 298), mais na nosa opinión trátase dunha atribución controvertida, non exenta de dificultades de tipo estilístico ou biográfico.

29 "Sin embargo, llegué á este / año de sesenta y quatro, / sin ser hombre de este siglo, / que antes dél me destetaron" (Obras VII 1781: 7). Talvez nestes versos estea a orixe da idea errónea de que Diego Cernadas nacera en 1698, seguida por numerosos autores (García Cortés 2002: 40).

30 "Á mí de caballero / por el voto de mi padre / no me toca el privilegio: / Que aunque era un hidalgo rancio, / (de los Andrades no menos) / por órdenes superiores, / que tuvo, me privó el serlo" (Obras VI 1780: 410).

31 "Por mal de mis pecados dexé la dulce, y util Compañía de mis respetables Padres de Monforte" (Obras VI 1780: 303).

32 "Que por la Sede Romana, / con título retumbante / de Apostólico Notario, / lo es hoy Marique, Terraque" (Obras VI 1780: 231). Véxanse tamén Obras VI 1780: 301 e VII 1781: 19. O dato corrobórao a documentación relativa á administración da capela de San Ramón de Bealo (Boiro, A Coruña), que se conserva na reitoral de San Pedro e que foi elaborada polo propio Carlos de Andrade en maio de 1760 (Piñeiro 2008).

${ }^{33}$ Segundo información facilitada por Anxo Rodríguez Lemos, Carlos de Andrade foi o encargado de dar fe pública ás constitucións da confraría da Virxe das Dores.

${ }^{34}$ Nun dos petitorios refírese a ela como Fanchuca (Obras VII 1781: 214). 
que debeu de padecer ao longo da súa dilatada vida ten unha última expresión na súa partida de defunción, onde se sinala que non deixou obra pía.

Outras informacións entresacadas dos petitorios coinciden de maneira coherente coa imaxe que del se dá na $L F D$. Non son raras nestes impresos anuais as mencións á afección do sancristán polo tabaco (Obras VI 1780: 258, 301-302; VII 1781: 237), aos pequenos furtos de viño ao cura (Obras VII 1781: 5, 216) ou ao seu estado de saúde, moi deteriorado nos últimos anos (Obras VI 1780: 235; VII: 209-210, 227-228). O desagrado que manifesta unha lavandeira por ter que lavarlle a roupa lixada de ourińos (vs. 114-118) ten tamén o seu correlato nun dos petitorios (Obras VII 1781: 211). E as palabras de Xerpe ao falar da súa vestimenta ("e a sua sotana negra, / que lle fai cando a tén posta / mercede en taparlle as pernas”, vs. 429-431) só acadan pleno significado ao descubrirmos nos petitorios que o sancristán tińa, ademais doutros defectos físicos, as pernas trencas ou tortas (Obras VI 1780: 259, 411; Obras VII 1781: 7, 30).

É sabido que o primeiro dos petitorios impresos polo Cura de Fruíme foi o de $1745^{35}$, e que o nome do sancristán non comezaría a aparecer á fronte deses textos ata dezaoito anos máis tarde, en 1763 (Fernández Salgado 2017: 84). Mais, por que motivo Carlos de Andrade asumiu entón a súa escrita (un asunto de certa importancia, tendo en conta que parte dos ingresos da confraría das Dores debía de proceder dos destinatarios desas publicacións)? O certo é que descoñecemos as causas reais que levaron a que o sancristán comezase a acometer ese traballo. Sabemos só que en certo momento (ignoramos o ano) se alude a que o esgotamento creativo de Cernadas fai perigar a aparición dun petitorio. Así o explica Carlos de Andrade nunha suposta misiva dirixida a un sancristán de Madrid:

Como te iba diciendo, la tal hermana Musa, de quien mi Cura se valía para su demanda, y que hasta ahora fué razonablemente fecunda, tuvo un golpe este próxîmo Septiembre, de que quedó inválida la pobre. [...] Por esta cuenta, amigo, no puedo este año darte gusto con el papelito que me pides, sino que Dios obre de milagro, porque no le veo traza de que el parto salga derecho (Obras VI 1780: 310, 312).

Fosen cales fosen os motivos de fondo, a verdade é que o sancristán era unha persoa idónea para substituír o cura na redacción dos petitorios; ademais de ser

35 Cońecido na actualidade unicamente pola versión incluída nas Obras en prosa y verso (Obras V 1780: 374-382; García Cortés 2002: 133-134). 
home de confianza de Cernadas, contaba cunha certa formación académica que o dotaba para a escrita e xa era afeccionado de seu á composición de poesías:

Por la crianza que tuve en la Escuela de la Compañía, donde nos mandaban hacer versos para la banda, unas veces por Cartago, otras por Roma, por la freqüencia con que entraba en el aposento del Padre Butron ${ }^{36}$, quando trabajaba la heroyca Vida de Santa Teresa, y últimamente por el compadrío que, dixe, tengo con la hermana Musa, Ermitańa de esta Sierra, se me pegó tambien algo de la manía, ó como llaman vena, y hago mis coplas quando quiero, como qualquiera hijo de vecino, que no en balde se dice, que en casa del Gaytero todos son danzantes (Obras VI 1780: 312-313).

Ese suposto gusto por facer coplas xa lle viña dos anos de xuventude, quizais de antes da súa recalada en Fruíme:

Si se hubiesen de imprimir las coplejas, que compuse quando mozo, para las Capillas músicas de mis Paysanitas en los Maytines, y Nocturnos de sus hiladas, á que yo concurria con el pandero, y las sonajas (que puestas en mis manos parecian un Archilaud) se podia hacer un libro de tanto tomo y lomo, como qualquiera de los del gran Piscator de Salamanca $^{37}$ (Obras VII 1781: 21).

O apuntamento da afección do sancristán pola composición poética, sempre que non se trate en realidade dun artificio de Cernadas, dá pé a considerar a posibilidade de que fose aquel, e non o cura, o autor das coplas dedicadas á Virxe na $L F D$, que se cantaron a petición dun dos romeiros. Isto explicaría que esas coplas non aparezan recollidas no manuscrito da RAG, ben porque Cernadas as considerou unha parte allea ao seu traballo creativo, ben por xa telas o sancristán memorizadas (as coplas foran cantadas anos atrás na mesma convocatoria relixiosa) e que por tanto se crese prescindible o esforzo de copiar o texto ou o gasto de papel.

${ }^{36}$ O xesuíta José Antonio Butrón y Mújica (1657-1734), nado en Calatayud, foi predicador, profesor de Humanidades e poeta. Autor dunha longa biografía en verso de Teresa de Ávila (Harmónica vida de Santa Teresa de Jesus, 1722), é coñecido en Galicia por participar nas Fiestas Minervales compostelás de 1697 ou por editar El clarín de la Fama, y cíhtara de Apolo (1708), relación das festas celebradas na cidade de Ourense para conmemorar o nacemento do príncipe Luis Jacobo.

${ }^{37}$ Isto é, Diego de Torres Villarroel (1694-1770), que empregou ese pseudónimo na famosa serie de almanaques e prognósticos (1718-1767). 


\section{DIEGO CERNADAS, DRAMATURGO}

Unha parte importante da produción dramática do Cura de Fruíme debeu de estar destinada ás representacións populares da romaría da Virxe das Dores, que se celebraba na parroquia de Fruíme cada terceiro domingo do mes de setembro (Obras VI 1780: 99) ${ }^{38}$. Grazas ao testemuño de María Francisca de Isla y Losa$\mathrm{da}^{39}$, sabemos dos esforzos que o cura dedicaba a preparar esas representacións anuais. A que fora súa amiga dinos que Diego Cernadas

procuraba divertirlos [os seus fregueses] con devotas poesías, haciéndoles representar varias loas, y ensayándolos á este efecto con tanta paciencia, que lograba hiciese cada uno su papel con mas propiedad de lo que podia esperarse de una gente del campo, que no tiene otra instruccion, que la de quando el pronóstico da siembra, observándolo tan exâctamente, como si lo que pone el Astrólogo por puro capricho fuera alguna profecía (Obras II 1778: xIv).

Resulta curioso que Isla y Losada non se refira neste texto a máis xéneros ca á loa, cando é evidente que no adro de San Martiño de Fruíme se representou tamén outro tipo de pezas breves. En calquera caso, das súas palabras parece poder interpretarse que na festividade das Dores se adoitaba levar á escena máis de unha obra, idea apoiada polo testemuño doutra loa conservada, en cuxa parte final dous personaxes, o gracioso Botica e a dama alegórica Devoción, anuncian e dan paso a un entremés:

$$
\begin{aligned}
& \text { Bottica]. Ola, digo, una palabra: } \\
& \text { por descargar mi conciencia, } \\
& \text { ya que me negué á la Loa, } \\
& \text { por ser esa una materia } \\
& \text { para mí muy revesada, } \\
& \text { si me lo toman en cuenta, } \\
& \text { un Entremes os ofrezco: }
\end{aligned}
$$

\footnotetext{
${ }^{38} \mathrm{O}$ terceiro domingo de setembro de 1775 foi día 17.

${ }^{39}$ Cóntao na biografía anónima incluída no segundo volume das Obras en prosa y verso (1778: VIII-XXI). A atribución deste texto á escritora compostelá quedou probada recentemente por Xosé Antonio Fernández Salgado (2017: 38, nota 9).
} 
¿Ustedes quiérenlo? Todos. Venga.

Dev[oción]. Pero ha de ser doctrinal.

Bot[ica]. Entre los Anacoretas

pudiera representarse,

que aunque yo cara no tenga

de Beato, ó Santurron,

sé muy bien en qué se peca.

Dev[oción]. Pues de este modo permito, que se represente (Obras VII 1781: 399).

Por outra parte, hai indicios que apuntan a que a tradición das representacións teatrais en Fruíme estivo en vigor durante bastantes anos da dilatada vida de Diego Cernadas, o que ao cabo seguramente orixinou un importante número de pezas. Fose como fose, de toda esa tradición hoxe apenas se conservan tres obras, ás que podemos engadir o título doutra máis, perdida na actualidade. Son as seguintes, en orde cronolóxica:

- [ca. 1760]. Coloquio entremesado entre el Sacristan, y los domésticos del Cura de Fruime, que en el dia de la fiesta de los Dolores gloriosos de Septiembre de este año lo representaron en el atrio de la Iglesia para divertir un breve rato á los Devotos menos recogidos. ${ }^{40}$

- 1762. Loa para la fiesta de los Dolores gloriosos de Maria SS. ${ }^{\text {ma }}$ en Fruime, dispuesta por lo mismo en estilo proporcionado à la capacidad de los Recitantes, $y$ del Auditorio. ${ }^{41}$

${ }^{40}$ Publicado postumamente no volume sétimo das Obras en prosa y verso (Obras VII 1781: 400-416). Non sabemos se houbo edición impresa anterior. Propońemos o ano de 1760 como data aproximada de redacción do texto baseándonos en que Carlos de Andrade declara nel ter 62 anos (p. 401), e tendo en conta que noutro lugar afirmara nacer antes do inicio do século XVIII (véxase arriba no apartado dedicado á súa biografía).

${ }^{41}$ Publicada por primeira vez en vida do autor (Cernadas y Castro 1762: 91-128) e integrada con posterioridade nas Obras en prosa y verso (Obras VII 1781: 368-399). 
- 1763. Auto Cómico, Histórico, Sacro. La Débora victoriosa, y la triunfante Jahèl. Dispuesto para solemnizar la fiesta de los Dolores gloriosos de Maria Santissima en Fruime. ${ }^{42}$

- [1775]. Loa para la fiesta de los Dolores de la Soledad de Fruime, representada por el Sacristan y Criados del S[eñ]or Cura, advirtiendo son ciertas las mañuelas que mútuamente se imputan.

Sabemos que estas pezas se representaban no adro da igrexa parroquial, para o que se dispoñía dunha rudimentaria infraestrutura teatral composta por un estrado ou tablado (Obras VII 1881: 405, 415) e unha mínima escenografía adaptada a cada caso. Os actores e actrices, como quedou dito, non eran profesionais, senón que se recrutaban entre os criados do cura, probablemente tendo en conta o talento ou a graza naturais de cada individuo. Todo parece indicar, en fin, que o sancristán Carlos de Andrade, ademais de actuar nesas funcións de maneira habitual, tiña certo peso na súa organización ${ }^{43}$.

Un caso singular é o de La Débora victoriosa, y la triunfante Jahèl, auto de temática bíblica que, ao parecer, foi representado por nenos ou rapaces novos ${ }^{44}$. Para un crítico da época, que describe o contido da peza e reproduce algúns dos seus versos, La Débora victoriosa constituía (a pesar das súas eivas formais) un instrumento encomiable para a instrución do auditorio ao que ía destinado:

Este mèthodo de representacion [refírese ao tipo de auto en que se encadra o texto] es sin duda loable. La Comedia ridiculiza el vicio: la Tragedia realza la virtud; pero un sucesso real, en que se halla visiblemente amable la virtud, y aborrecible el vicio, tiene mas poder, que los mejores discursos sobre gentes poco entendidas, ò de una edad corta, mas

${ }^{42}$ Obra de localización descoñecida que publicou en Santiago a "Imprenta de D. Pedro Fraiz" (Langlet 1763: 28).

${ }^{43} \mathrm{Na}$ Loa de 1762 o personaxe por el interpretado recita unhas elocuentes palabras ditas supostamente por Cernadas: "Carlos, mi buen Sacrismoche, / tú ya sabes, que este dia / para nosotros es doble / de primera clase, y que / en los años anteriores / siempre se hacia un festin, / en que tú con los consortes / de la casa disponias, // por alegrar los señores, / que vienen á la funcion, / decir quatro relumbrones / en una Loa” (Obras VII 1781: 370-371).

44 "Los Actores unos jovenes inocentes, que explican con la voz los afectos mismos en que su tierna devocion los inflama” (Langlet 1763: 29). Foron estes jovenes inocentes os alumnos de Carlos de Andrade? Non podemos aseguralo, aínda que sabemos que alumnos seus si participaran na Loa de 1762 interpretando unha Salve (Obras VII 1781: 389). 
sensibles siempre à las pinturas, y à los exemplos, que à los pensamientos mas discretos (Langlet 1763: 32).

Sen dúbida, o público de todas estas representacións estaría composto, fundamentalmente, polos veciños da parroquia de Fruíme, labradores na súa meirande parte, pero tamén por romeiros chegados doutros lugares, polos sacerdotes que asistiran nos oficios relixiosos e, seguramente, por algúns personaxes significados da zona ou amizades de Cernadas que acudisen ao lugar no día da festa. Na Loa de 1762 e no Coloquio entremesado os personaxes diríxense aos principais grupos sociais e humanos que configuraban o auditorio e, entre eles, faise mención explícita a relixiosos e sacerdotes, a cabaleiros, a forasteiros, a labradores, a mozas e mozos e, finalmente, ás vellas, que non saen nada ben paradas (Obras VII 1781: 398-399, 414-415).

A finalidade primordial da representación desta clase de pezas era, certamente, o entretemento dos fieis chegados á romaría da Virxe das Dores, de aí que fose frecuente o recurso á comicidade, en ocasións buscando a gargallada a través da humorada chocalleira característica do xénero. Con todo, e como é lóxico imaxinar, nas obras non se descoidaba o aspecto relixioso (dalgunha maneira contribuían a fomentar a devoción colectiva pola Virxe) e, por suposto, tamén eran utilizadas como un eficaz instrumento pedagóxico destinado ás clases populares ${ }^{45}$.

Non é difícil imaxinar que a fama destas pezas excedese axińa os límites da freguesía de Fruíme e que os textos dramáticos de Cernadas y Castro fosen solicitados para solemnizar festas patronais ou outras celebracións en lugares máis ou menos distantes. O propio cura relata nun dos seus poemas como nun par de ocasións lle foron requiridas loas que logo non se lle pagaron. $\mathrm{O}$ fragmento que inserimos a continuación é extenso, pero paga a pena a súa reprodución para que se cońeza o modo en que Cernadas procedía ao compoñer este tipo de obras (obviamos a transcrición das partes consideradas menos relevantes para o tema que nos interesa):

$$
\begin{aligned}
& \text { En llegando qualquier mozo } \\
& \text { con una gorrilla puesta, } \\
& \text { ya viene el criado, y dice, } \\
& \text { que está un Seńor á la puerta: [...] }
\end{aligned}
$$

45 É o caso da Loa de 1762, en que se relata a fundación da Orde dos servitas (Obras VII 1781: 391-396), ou tamén, claro está, o da posta en escena de pasaxes bíblicas, como ocorre en La Débora victoriosa. 
Lo mas insufrible á veces, es que quando un hombre piensa, que es por algo de importancia, se halla con una friolera.

Mi Dueño (dice) frado en su gran honra, y sus prendas: (mejor diría: en el juicio de que es usted un badea):

Pongo en su noticia, que aqui se hace una Comedia al milagroso San Roque, del mal extraño defensa.

Necesitase una Loa, que si es parto de su vena, hará mas fantasiosa y mas solemne la fiesta.

Dar la vida por su Dama ${ }^{46}$ es el titulo, y se intenta, que no sean mas que quatro personas que hablen en ella.

El nombre del Mayordomo es Domingo Castiñei[r] $\mathrm{as}^{47}$, del Consejo del Pesillo, Factor de la Real Hacienda.

Hace la función por voto de su muger Marimenga, que hubo de morir de peste de una fluxîon á las muelas.

Música poca, ó ninguna; $y$ si es que alguna se mezcla,

${ }^{46}$ Comedia de Luis Coello que se coñece por unha edición madrileña de 1754 (file:///C:/Users/Usuario/ Downloads/comedia-famosa-dar-la-vida-por-su-dama\%20(1).pdf), pero que foi composta necesariamente antes dese ano: o texto de Cernadas en que aparece referida debeu de redactarse en 1751, segundo se desprende do seu título (Obras VI 1780: 130).

${ }^{47}$ No impreso, por erro, Castiñeitas. 
ha de ser á la guitarra

por las folias francesas.

Que traiga su elogio al Cura,

que es del arte, pues si reza,

dos versiculos ajusta

al Domine labia mea.

Esta obrilla en ocho dias

de su habilidad se espera.

Suya, dos de Agosto ${ }^{48}$. Su

siervo, que su mano besa.

¡Válgame el Santo bendito!

¿que hasta con su nombre quieran

á un pobre Cura pegarle

semejantes pestilencias?

El caso es, que en ocasiones,

por circunstancias diversas,

no puede excusarse un hombre

de tales impertinencias.

Consiente, dobla el papel, da por el quarto dos vueltas, atusa la fantasía, y galantea la idea.

Toma la pluma, echa un rasgo, esto borra, aquello enmienda, un concepto se resiste, otro asoma; pero no entra. [...]

Así pasa algunos dias, hasta acabar su faena, coplas quando se levanta, y coplas quando se acuesta.

Versos de noche y de dia,

${ }^{48}$ Repárese en que a festividade de San Roque se celebra o 16 de agosto; desta maneira, tras a semana proposta para a composición da loa, aínda se dispońería de cinco ou seis días para o estudo do texto e os ensaios pertinentes. 
consonantes quando vela, consonantes quando duerme, porque hasta con ellos sueña.

$\mathrm{Al}$ cabo, como es preciso poner en limpio la pieza, á la tarea que acaba sobreviene esa molienda.

Pónese á sacar la copia, y aquí nuevo afan empieza, porque unos versos ańade, otros pule, y otros peyna.

Al fin sacó su traslado, y como el plazo le aprieta, para cumplir su palabra hace un propio de su cuenta.

Llega la obrita al amigo, y doy que á su gusto llega, darle el recibo, y las gracias son por postre la respuesta. [...]

¡Y por todo un cartapacio de coplas con afán hechas, sobre sudar, discurrir, poner papel, tinta, oblea:

Dormir poco, comer menos, y pagar propios, siquiera no le han de dar al Autor parvas para una Quaresma! [...]

Vez hubo, que sin tener conmigo otra inteligencia, mas que la de haberme hallado de camino en una venta,

Uno me escribió despues, pidiéndome que le hiciera una Loa á San Mamed, 
que era el Patron de su Iglesia ${ }^{49}$.

Valióse de un pretextillo, que obligaba á mi obediencia, y que quise que no quise, al fin fué preciso hacerla.

Como es Santo extravagante, de que por acá no rezan, no tenia de su vida la noticia mas pequeña:

En mi estante no la hallaba, y hube de hacer diligencias, porque me prestasen un Flos Sanctorum de Villegas ${ }^{50}$.

Quedé deudor de esta gracia, gasté un poco en su leyenda, busqué la invencion, y en fin hice la Loa: copiéla:

Remitíla con un propio, todo á mi costa: ¿y qué piensas que me valió? Pues lo mismo ni mas, ni menos que aquella (Obras VI 1780: 132-139).

Poderiamos, en fin, mencionar aínda a loa que compuxo Diego Cernadas para a función con que os oficiais da Real Fábrica de Jarcia de Sada celebraron en 1761 o cuadraxésimo quinto aniversario de Carlos III ${ }^{51}$, ou tamén a loa de carácter alegórico representada en 1756 polos dependentes da praza da Quintana, en

\footnotetext{
${ }^{49}$ No Nomenclátor de Galicia figuran 89 parroquias cuxo titular é San Mamede, pero ningunha delas está no municipio de Lousame. Preto de Fruíme si existe un monte chamado San Mamede, na parroquia de San Pedro de Tállara, onde se localiza unha ermida erixida en 1746. Con todo, a dita capela encóntrase baixo a advocación de San Lourenzo, polo que probablemente non se trata do lugar para o que se compuxo a loa referida.

${ }^{50} \mathrm{O}$ toledano Alonso de Villegas (1533-1603) foi, efectivamente, autor dun cońecido Flos sanctorum que se publicou en seis volumes entre 1578 e 1603 e que obtivo grande éxito editorial.

${ }^{51}$ Información procedente do testemuño do ilustrado José Cornide y Saavedra, que ao parecer contribuíu a organizar a dita función (Murguía 1917: 165-166).
} 
Santiago de Compostela, que se conserva inédita no segundo volume do códice de Décimas y Romances da Biblioteca Xeral da USC ${ }^{52}$.

A partir dos textos cońecidos, aínda que representen apenas unha mínima parte da súa produción dramática, é posible facérmonos unha idea do espazo que, en lińas xerais, o Cura de Fruíme reservou para a lingua galega neste xénero de obras.

En primeiro lugar, pódese comprobar que o castelán é a lingua empregada de maneira exclusiva nas pezas de tipo alegórico (con personaxes como a Devoción, a Música, o Afecto...) e nas representacións de pasaxes bíblicas, independentemente de se estaban dirixidas a un público urbano (como a Loa compostelá de 1756) ou rural (o caso de La Débora victoriosa).

A práctica lingüística habitual dos actores e actrices - lembremos, todos eles non profesionais - non parece que condicionase a elección dunha ou doutra lingua para os personaxes que ían representar: os nenos e nenas de Fruíme que interviñeron en La Débora victoriosa moi probablemente serían galegofalantes; quen fixo de Labradora ou Lavandeira na Loa de 1762 interveu en galego pero tamén recitou unha longa composición en castelán; o sancristán Carlos de Andrade, que participou nas obras de ca. 1760, 1762 e 1775 sempre en castelán, é posible que tamén se expresase en galego de modo espontáneo na súa vida diaria ${ }^{53}$.

A lingua galega, en fin, parece quedar relegada para os papeis de criado ou aldeán. Así, na $L F D$ interviñeron en galego Xerpe, criado de Diego Cernadas que interpreta o mesmo personaxe, e os catro romeiros aldeáns que entran na segunda escena ${ }^{54}$. No Coloquio entremesado de cara a 1760 falaba orixinalmente en galego Botica, e talvez tamén o fixesen os personaxes de Capucho e Basilio

${ }^{52}$ Leva por título Loa para introduccion dela Comedia Los Votos de Santiago, y Batalla de Clavijo, que en honra del unico y singular Patron delas Españas el Grande Apostol Santiago el mayor representaron los dependientes de la Quintana en este año santo de 1756.

${ }^{53}$ No impreso titulado Kalendario doloroso, que contén un suposto diálogo —en castelán — entre o cura e o sancristán, comprobamos que este último arranca a conversa en galego: “ $E$ vos, què facedes, meu Crego? Parece que hay murria?" (Cernadas y Castro 1762: 23). Con todo, os seus anos de formación nos xesuítas de Monforte, o seu traballo como mestre (e notario apostólico) e o propio testemuño dos textos dramáticos (en que o personaxe representado se pode identificar coa persoa) apuntan a que a súa lingua de expresión habitual debía de ser o castelán.

54 A orixe rural dos catro personaxes queda manifesta cando Ciprián lle propón a Tereixa regresaren ao seu lugar de procedencia: "E agora, Tereixa, / vaya recollendo os lotes, / que he tempo dir para a aldea" (vs. 477-479). Outros elementos caracterizadores da súa rusticidade achámolos nos instrumentos musicais que utilizan (pandeiro, ferreñas, castańolas), na melodía que interpretan (a muiñeira) e, seguramente, 
(con intervencións moito máis breves, case anecdóticas), todos eles caracterizados como "domésticos del Cura de Fruime" (Obras VII 1781: 400). Mais como se explica na nota que vén despois do título na edición das Obras en prosa y verso, Diego Cernadas tivo que traducir ao castelán a parte dos diálogos que estaba en galego:

Este papel, que leido apenas tendrá gracia, tuvo alguna representado, porque los interlocutores fueron propia, y personalmente los mismos que lo executaron, y cada uno hablaba con sus propias modales. El de Botica estaba en Gallego, y aquí (porque el Señor Mones apostató de serlo) se pone en Castellano, pero á costa de perder mucha sal de la que tendría en nuestro idioma (Obras VII 1781: 400).

$\mathrm{Na}$ Loa de 1762 só emprega a lingua galega (ademais do castelán) a personaxe da Labradora ou Lavandeira, fronte ás dúas personaxes alegóricas (a Devoción e a Música), un Peregrino orixinario de Noia, o sancristán Carlos de Andrade e Botica, neste caso representando o papel de gracioso (Obras VII 1781: 368).

Así as cousas, é posible afirmar que as obras referidas constitúen un reflexo fidedigno da realidade sociolingüística da época? Cremos que non. Aínda que desde a segunda metade do século Xv o galego se viu inmerso nun contexto de diglosia social que o apartou do desempeño das funcións formais e puxo en marcha un proceso de deserción entre a aristocracia, este abandono tardou en xeneralizarse entre a nobreza alta e máis aínda entre a fidalguía e o patriciado urbano. Sendo aínda mozo Diego Cernadas, o fidalgo Plácido Feijoo escribiu en 1723 que o galego fora a lingua en que el se criara, afirmación que se pode corroborar acudindo a outra exactamente igual que se fai no "Pranto da frota por unha ninfa galega” (1702), que, se non é obra do padre Feijoo, irmán de Plácido, deberase a alguén do mesmo círculo familiar (cf. Álvarez / Millán Rodríguez 2016: 264). Pouco despois, arredor de 1740, o beneditino Sarmiento, que tamén se criara en galego na Pontevedra de entre 1695 e 1710, dicía o seguinte do idioma galego: "Háblanle todos, así señores, como rústicos" (cf. Mariño Paz 2008: 123-126). Sabemos que Isabel Sanjurjo Gayoso y Montenegro, marquesa consorte de Valadares (?-1762), utilizaba o galego de maneira espontánea, como pon de manifesto a declaración realizada polos caseiros Silvestre Bernárdez e Ma-

na súa onomástica; ademais hai que supoñer que a indumentaria empregada na posta en escena tamén apuntaría nese sentido. 
ría Ventura Álvarez durante o xuízo pola morte de Benito Alonso Henríquez y Sarmiento, IV Marqués de Valadares, en 1757 (Giraldo 1766: 14r, 14v, 204v e 205r). E no mesmo tempo en que Cernadas escribiu a $L F D$, a dama compostelá María Francisca de Isla, súa amiga, compúxolle unha carta en verso na que exhibe un galego tan fresco e expresivo, tan cargado de trazos da oralidade coloquial, que non podemos senón pensar que ela debía de expresarse acotío na lingua en que nesa carta se dirixiu a don Diego (cf. Mariño Paz 2007).

Parece, por tanto, que debe de haber xa moito de tópico literario na figura do aldeán ou criado de orixe aldeá que o Cura de Fruíme asocia indefectiblemente á lingua galega. Na realidade, estabamos xa nesa altura ante un personaxe ben asentado na dramaturxia popular de Galicia. En efecto, se se repara no perfil socioprofesional dos personaxes galegofalantes do teatro dos séculos XVI a XVIII, é doado advertir que a práctica totalidade deles ten orixe no rural ou se dedica aos labores do campo ${ }^{55}$. É dicir, a lingua galega acabou por converterse nun elemento caracterizador dun tipo de personaxe en boa medida estereotipado, un trazo que, xunto co da vestimenta ou os dos cantos e bailes populares, conformaba un paquete que se opoñía netamente ao conxunto de condutas propias dos individuos instruídos e urbanos, máis inclinados a adoptar as modas cortesás. O castelán, en cambio, foise consolidando como a lingua dos personaxes non marcados pola súa rusticidade ou, en todo caso, daqueles non pertencentes ás clases populares. Esta norma, como é sabido, non se contravirá ata moito tempo despois, cando a lingua galega reciba o pulo normalizador das Irmandades da Fala, xa iniciado o século xx.

\section{SUMARIA CARACTERIZACIÓN LINGÜÍSTICA}

Moi sucintamente, lonxe de toda pretensión dunha análise pormenorizada, apuntaremos nas próximas páxinas algúns trazos lingüísticos que poden arrequentar

55 É o caso do Entremés dos pastores (1594), o Diálogo de Alberte e Bieito (ca. 1596), a Contenda dos labradores de Caldelas (1671), o Entremés ao feliz e real parto da nosa raiña (1707) ou o Entremés do portugués (1710). Dos personaxes do actualmente extraviado "Papel de Toribio" (entremés do século xvin??) apenas temos información (Carballo Calero 1978: 103, 112), mais no teatro do Século de Ouro español o nome de Toribio asóciase con frecuencia a personaxes rústicos de Galicia e Asturias, o mesmo ca o de Dominga no caso das mulleres (no texto, baixo as formas hipocorísticas Mingota e Mingotiña). 
tanto o noso coñecemento desta loa e das circunstancias da súa composición e transmisión coma o saber ata hoxe acumulado sobre o galego medio.

No terreo dos usos gráficos cómpre deterse sobre todo no tocante á representación do fonema fricativo prepalatal xordo. Se no uso manuscrito o emprego exclusivo de $<\mathrm{x}>$ para representar esta consoante debeu de ir abríndose paso pouco e pouco na obra de Cernadas, esta práctica simplificadora consagrouse despois nas pezas en galego que se incluíron nas súas Obras en prosa y verso dadas ao prelo en Madrid entre 1778 e 1781 (cf. Monteagudo 2005: 415-419; Mariño Paz 2017: 487-488). No caso da copia da $L F D$, non podemos desvincular o uso de $<j>,<$ g $>$ e $<x>$ que nela se observa do feito de que lla debamos á man de Antonio de la Iglesia, quen, como ben se sabe, fixo en 1888 profesión de fe etimoloxicista e historicista en materia ortográfica (Iglesia 1888) e como editor significouse, polo menos desde a publicación do Album de la Caridad en 1862, polo seu empeño de corrixir a representación fonoloxicista do fonema $/ \int /$ nos textos en que a atopaba. No que neste traballo abordamos vemos, en efecto, moitos usos acordes coa etimoloxía ou coa historia das palabras ( $j a$, vs. 74, 235, 270...; Jesús, vs. 286, 466; junta, v. 332; juntou, v. 349; justiños, v. 308; gente, v. 357; rege, v. 281; Virgen, vs. 11, 229, 241...; caixa, v. 89; deixemos, v. 93; déixense, v. 379; exempro, v. 409; etc.), mais tamén outros que non o son (ajiña, v. 480; foxe, v. 2; vexa, vs. 196, 263, 349; etc.), e algunhas contradicións (Axiña, v. 256, e ajiña, v. 480; hoxe, vs. 6 e 235, hoje, vs. 270, 348 e 411 e oje, v. 344; sexa, v. 29, e seja, v. 253). Coa escritura da palabra encaijes (v. 428) tivo dúbidas don Antonio, xa que o seu $<$ j $>$ parece corrixir un $<$ g $>$ anterior.

Para a representación da consoante nasal velar en posición intervocálica a $L F D$ presenta o dígrafo $<\mathrm{nh}>$ (unha, vs. 300, 333, 380, 413, 481; unhas, v. 454; Vnha, v. 251), é dicir, o mesmo que aparece nas obras manuscritas e impresas do Cura de Fruíme que cońeciamos ata o de agora (cf. Mariño Paz 2017: 462).

Canto aos niveis fonético, fonolóxico e morfolóxico, o manuscrito que analizamos presenta distintas variantes lingüísticas que ao noso entender cadran ben coa localización espacial e temporal de Diego Cernadas, que basicamente viviu entre Santiago de Compostela e Fruíme (concello de Lousame) entre 1702 e 1777. Trátase ademais de solucións ou usos xa ben atestados na obra en galego que ata hoxe lle cońeciamos a este autor, unhas veces como variantes utilizadas de forma exclusiva, noutras ocasións como variantes moi maioritarias: 
1. Formas de plural uns (v. 313) e algúns (v. 320), e non us nin algús.

2. Non mao, senón man (v. 401) como resultado da voz latina MANU(M).

3. Bo (vs. 246, 264, 342, 346), e non bon, como solución para o latín BŎNU(M).

4. O ditongo /'oi/ como desenvolvemento histórico da secuencia latina -ǓLT-: moito (vs. 7, 63, 99, 432), moita (vs. 297, 408), escoite (vs. 209, 226).

5. Indicios de seseo prenuclear en xirimoñas 'cerimonias' (v. 405), pois a palatalización da súa consoante inicial só se explica a partir da existencia dunha fricativa predorsal ou apical, e nunca desde unha interdental. Non abundan, mais na restante obra en galego de Cernadas hai algúns rexistros explícitos de seseo prenuclear (cf. Mariño Paz 2017: 482).

6. Variantes con eliminación da semiconsoante velar no grupo latino QUseguido de /a/ tónico ou átono: cadra (v. 445), cando (vs. 268, 290, 331, 430, 467), cantos (v. 305), carto (vs. 298, 328), cartos (vs. 121, 285), catro (vs. 308, 314), catrocentos (v. 314) e corenta (v. 307). Só se exceptúa cuando (v. 153).

7. Ti (vs. 287, 347), non $t u$, como pronome persoal suxeito da P2.

8. O alomorfo pronominal de terceira persoa nos, e non os, como complemento directo situado despois dunha forma verbal terminada en ditongo: pillounos 'a eles' (v. 330). Esta innovación, que aflora xa no Cancioneiro de Afonso Pérez de entre finais do XIV e principios do XV, conta tamén con outros rexistros nas fontes do galego medio (cf. Varela Barreiro 2015a).

9. Alternancia entre o tratamento de vós (v. 261) e o de ti (vs. 287, 347) entre os compadres Pepe, Tereixa, Ciprián e Catuxa ou entre persoas de semellante condición social (de Xerpe a Tereixa, vs. 486, 487), mentres que o de vosté, vostedes ou ustés é o que se impón cando a relación se dá entre unha persoa situada nun nivel xerárquico inferior e outra ou outras xerarquicamente superior ou superiores (do criado Xerpe ao sancristán Carlos, v. 1, 15, 27...; de Ciprián a Carlos, vs. 446, 449, 452; de Tereixa a Carlos e Xerpe, v. 358; de Pepe a Carlos e Xerpe, v. 378) ou entre persoas entre as cales non hai proximidade ou familiaridade (de Tereixa a 
Xerpe, v. 398; de Xerpe a Ciprián, v. 434). En castelán, o sancristán Carlos trata de tú (vs. 8, 9...) o criado Xerpe, xerarquicamente inferior. Nas invocacións á Virxe óptase por vós (vs. 230, 244).

10. Alternancia entre variantes con síncope de /d/ intervocálico (asistime, v. 244) e sen esa síncope (botad[e], v. 260; dade, v. 342) na P5 do imperativo, con 'cero' ou -de como sufixo número-persoal. No presente de indicativo temos o esperable tendes (v. 486) das terras de Lousame e un probable caso de sufixo número-persoal $-s$, pois, polas razóns que máis abaixo expoñemos, inclinámonos a pensar que tragés (v. 258) é unha forma de P5 de traguer con gheada.

11. Distintas variantes da morfoloxía verbal irregular:

A. DAR: P3 dou (v. 297), e non deu, no pretérito de indicativo.

B. $\mathrm{DECIR}^{56}$ : no presente de indicativo, a variante conservadora dices (v. 286), con lexema dic-, alterna en desvantaxe coas innovadoras di (v. 119) e din (vs. 301, 322, 324, 333); a medida do verso determina ás veces a escolla dunhas variantes ou outras. Este dato está en consonancia co aumento dos rexistros que destas solucións innovadoras se dá no conxunto das fontes galegas da segunda metade do século XviII, entre elas todas as do Cura de Fruíme (cf. Mariño Paz 2019: 99-103).

C. FACER: como P3 e P6 do presente de indicativo rexístranse fai (v. 430) e fan (v. 387), sen rastro das conservadoras faz e facen. Este feito tamén está en consonancia co conxunto de datos que sobre esta cuestión se poden recadar nas fontes do galego medio, que mostran que na P2, na P3 e na P6 do presente de indicativo de facer a mudanza de fazes para fas, de faz(e) para fai e de fazen para fan foi máis temperá ca no análogo caso do verbo dicir (cf. Mariño Paz 2019: 104-105).

D. OÍR. Todas as formas deste verbo que se detectan na $L F D$ remiten a oir, e non a ouir, nin a ouvir nin a ouguir: oir (v. 302), oilas (v. 469),

${ }^{56}$ Esta é a única forma do infinitivo que se rexistra no texto para este verbo (vs. 307, 452), nunca decer nin dicir. 
oin (vs. 307, 452). Este dato casa ben cos datos extraíbles doutros textos de Cernadas e co uso que o ALGa 1 (mapa 308) daba para esta variable en Compostela e Lousame cara ao final do século Xx.

E. PODER. Sobre o presente de subxuntivo poida (v. 153) cómpre subliñar que o ALGa 1 (mapa 314) tamén o sitúa en Santiago de Compostela, así como en localidades da banda norte da ría de Arousa ou do curso final do río Ulla non moi distantes de Fruíme. Así mesmo, nos textos composteláns de principios do século XIX predominan claramente estas variantes con lexema poid- (cf. Mariño Paz 2003: 236).

F. PÓR. Todas as formas utilizadas remiten a pór, e nunca a un poñer que, cómpre advertilo, faría hipermétricos os versos que aquí citamos: pór (v. 219), póndome (v. 195), porá (v. 156). Como se mostra noutro capítulo deste mesmo libro (cf. Mariño Paz), se na obra de Antonio Cernadas prepondera con claridade o modelo de pór sobre o de poñer, esta preponderancia pódese presumir tamén para o conxunto do galego do seu tempo, pois ao finalizar o século XVIII o avance de poñer a custa de pór en dirección norte-sur e leste-oeste estaba menos estendido ca hoxe.

G. SER. $\mathrm{Na} P 1$ do presente de indicativo a $L F D$ ofrece so 'eu son' (v. 501), unha variante conservadora que tamén comparece noutro texto de Cernadas e no romance da dama compostelá María Francisca de Isla (1775), así como noutras fontes que en conxunto mostran que a mediados do século XVIII esta solución debía de circular aínda moito polo occidente da actual provincia da Coruña (cf. Álvarez 2018: 23); nos textos de principios do século XIX tamén se usou con certa frecuencia (cf. Mariño Paz 2003: 243). No presente de subxuntivo alternan sea (v. 351) e un seja (v. 253) que se revela como moi frecuente nas fontes dos séculos XVII e XVIII (cf. Mariño Paz 2003: 244 e Gondomar).

H. TER. Na P6 do presente de indicativo úsanse tanto ten (v. 123) como teñen (v. 320), sen que a súa escolla estea condicionada nin 
pola medida nin pola rima dos octosílabos; isto cadra cos datos de conxunto do galego medio e cos da obra de Diego Cernadas, nos que se impoñen indiscutiblemente as formas de P6 ten, ven e pon (cf. o capítulo de Mariño Paz neste mesmo libro). Para os tempos do tema de pretérito só se documenta o lexema tiv-, bastante estendido nas fontes do galego medio e moi frecuente nas do século XIX (cf. Mariño Paz 2003: 246-248): tiven (v. 458), tivera (v. 218), tivese (v. 402).

I. TRAGUER. Remite inequivocamente a traguer a P1 do presente de indicativo trago (v. 255), e estamos convencidos de que o mesmo acontece con tragés 'traguedes' (v. 258), que para nós é unha forma de P5 do presente de indicativo con gheada e con $-s$ como sufixo número-persoal. Casa con esta nosa interpretación o feito de que traguer sexa moi abundante nas fontes do galego medio e das primeiras décadas do século XIX, e especialmente a circunstancia de que en varias tertulias compostelás de principios do oitocentos se opte por trager ou trajer, con gheada, e por formas conxugadas como as de presente de indicativo trage e tragedes e a de imperativo tragéo (cf. Gondomar; Marińo Paz 2003: 248-251).

J. VAlER. A P3 do presente de indicativo val (v. 285), con apócope da vogal temática, é a variante que predomina ostensiblemente na obra de Cernadas, no conxunto das fontes do galego medio e nas de principios do século XIX (cf. Gondomar e Mariño Paz 2003: 210).

12. Acá e alá, e non acó nin aló, como adverbios de lugar que expresan movemento intralocal (v. 254), situación (v. 283) ou localización indefinida no tempo pasado (v. 268).

Con suma concisión, con laconismo estrito, anotamos para acabar algúns outros trazos lingüísticos da $L F D$ que adoitan aparecer no conxunto das fontes do galego medio. No plano fonético chamaremos a atención sobre os fenómenos de síncope vocálica (Sobrana, v. 455) e de metátese (Calros, vs. 1, 61, 438...; porveito, v. 346; Probe, vs. 151, 235, 237), sobre a monotongación popular de 
ditongos crecentes en concencia (v. 279), convenencia (v. 417) e pacencia (v. 297), sobre a persistente tendencia a mudar por vibrante a consoante lateral alveolar dos grupos consonánticos homosilábicos dos cultismos (crara, v. 453; exempro, v. 409; supricar, v. 484; etc.) ou sobre a transformación en /n/ do grupo consonántico heterosilábico /gn/ en iñorando (v. 424), abundantemente documentada na literatura dos séculos XIx e xx e explicitamente recońecida por Saco Arce na súa Gramática gallega de 1868 (cf. Mariño Paz 2012: 342-343). É singular o rexistro de aceita 'acepta' (v. 369), pois nas fontes do galego medio ata o de agora cońecidas non se observa semiconsonantización de /p/ na coda silábica dos cultismos (cf. Mariño Paz 2017: 519).

O adverbio modalizador seique (v. 99), que no manuscrito da $L F D$ se escribe xunto, é dicir, sen análise dos seus dous constituíntes orixinarios (a forma verbal e a conxunción completiva), ten tamén certa circulación noutras fontes dos séculos XVII e XVIII (cf. Gondomar). E canto á perífrase modal obrigativa ter de + infinitivo (v. 406), cómpre ponderar que tamén se le no Entremés gallego (1707) de Salvador Francisco Roel (cf. Gondomar) e con notable frecuencia en textos decimonónicos de extracción popular (cf. Freixeiro Mato / Sánchez Rei / Sanmartín Rei 2005: 536-538), así como na carta que Magdalena de Ogando lle enviou ao padre Sarmiento por volta de 1755 , na que ten un valor non obrigativo, senón prospectivo (cf. Marińo Paz 2014: 70, 74).

No terreo do léxico Diego Cernadas exhibe na $L F D$ un rico vocabulario patrimonial non interferido, con voces antigas no idioma como abroque (v. 334), cirolas (v. 105), eibas (vs. 94, 294), embeja (v. 84), faceiras (v. 289), freigueses ${ }^{57}$ (v. 320), goufas (v. 90), má (v. 207), ouriñas (v. 103), etc., pero non sen acusar a pegada do castelán, sobre todo no campo semántico da relixión (alababa, v. 456; alabanza, v. 468; capellán, vs. 238, 284; Dios, vs. 225, 397, 407; [Virgen] dos Dolores, vs. 229, 241, 242, 418, 456, con xénero masculino), mais non só: polvo (v. 92) e polviño (vs. 31, 67) 'de tabaco', Reina (v. 455), testigo (v. 366)... Hipergaleguismo de motivación purista témolo en esperenza (v. 66). Finalmente, no ámbito da fraseoloxía hai que mencionar topar menos 'botar en falta' (v. 416) e o calco castelanizado de Deus diante! que Fruíme puxo nos labios do sancristán Carlos: Dios delante (v. 475).

\footnotetext{
${ }^{57}$ Sobre a multisecular resistencia de freguesía ante parroquia durante a Idade Media e a Idade Moderna, e mesmo ata hoxe, cf. Varela Barreiro (2015b).
} 


\section{EDICIÓN}

Presentamos a continuación a nosa proposta de edición da $L F D$. Nela pretendemos ser fieis ás particularidades gráficas e lingüísticas do texto, pero, ao mesmo tempo, facilitar o acceso á súa lectura e comprensión. Por este motivo optamos por non modernizar máis ca a acentuación, a unión e separación de palabras, a puntuación e o uso de maiúsculas e minúsculas, tendo en conta as normas e convencións vixentes tanto para o galego coma para o castelán ${ }^{58}$.

No caso da acentuación, prescindimos do uso do diacrítico na $\mathrm{P} 3$ do presente de indicativo do verbo ser, dado que o autor (ou o copista) resolveu a homografía $\mathrm{da}$ forma verbal e da conxunción copulativa mediante un $\langle\mathrm{h}\rangle$ non etimolóxico para o primeiro caso (he), solución con presenza na lingua escrita xa desde o período medieval. Excepcionalmente botamos man do diacrítico en dous exemplos en que falta a letra $<$ h $>$ no verbo (vs. 426 e 436). Por outra parte, decidimos manter o acento gráfico da voz bóta 'recipiente de coiro para o vińo' (vs. 254 e 368), por considerar que ten función diacrítica no texto (cf. bota, do verbo botar, v. 338) ${ }^{59}$.

Canto á unión e separación de palabras, pareceunos conveniente non intervir en dous casos, co fin de non ocultarmos información sobre a articulación do elemento nasal de final de palabra na cadea fónica: Nono nego (v. 292) e beno entendan (v. 441). En cambio, si aglutinamos a contracción da preposición con e o artigo unha en counha moza frescacheira (< co unha moza frescacheira, v. 413), da mesma maneira que fixemos en coa bóta (<co a bóta, v. 368) ou en coa festa (<co a festa, v. 411). Tamén botamos man do apóstrofo en tres ocasións, para marcar a elisión dunha vogal ao final de palabra, seguindo outros exemplos presentes no manuscrito: qu'eu sempre (< queu sempre, v. 15), d'oje en vinte anos (< doje en vinte anos, v. 344) e he tempo d'ir para a aldea (< he tempo dir para a aldea, v. 479).

$\mathrm{O}$ inicio de cada páxina do manuscrito que contén a $L F D$ vén sinalado na nosa edición mediante un díxito seguido dunha letra entre ángulos $(<5 \mathrm{a}>)$, que remiten, respectivamente, á numeración orixinal de cada prego (véxase a descri-

\footnotetext{
${ }^{58}$ Remitimos os lectores interesados en coñecer as solucións orixinais do texto á reprodución dixital do manuscrito que se pode consultar actualmente no Arquivo Dixital de Galicia (véxase nota 6). Así mesmo, está prevista a inclusión da $L F D$ no repositorio Gondomar (2017), onde se posibilitará o acceso a distintos tipos de edición da peza.

${ }^{59} \mathrm{O}$ acento con valor diacrítico aparece claramente empregado no manuscrito no caso da contracción da preposición a e o artigo determinado masculino (vs. 192, 282, 317, 476 e 482).
} 
ción do manuscrito no apartado 2) e á páxina que dentro deste ocupa o texto. Así, por exemplo, $<5$ a $>$ corresponde á primeira páxina do prego número 5, mentres que $<7 \mathrm{c}>$ corresponde á terceira páxina do prego 7 .

Seguindo a práctica habitual, utilizamos a letra cursiva para o desenvolvemento das abreviaturas (Sor. $>$ señor, no título) e para unificar a representación das didascalias. Entre corchetes e con letra redonda puxemos a corrección dos erros de copia detectados (oiros >o[t]ros, v. 47; poira > po[t]ra, v. 99).

Finalmente, naqueles versos en que interveñen dous personaxes optamos sempre por distribuír en liñas diferentes a parte de diálogo correspondente a cada un deles, introducindo ademais unha sangría na segunda liña, de modo que se perciba con claridade que as dúas partes integran un mesmo verso (vid. vs. 61, 215, 220 etc.).

$<5$ a $>$ Loa para la fiesta de $\operatorname{los}^{60}$ Dolores de la Soledad de Fruíme, representada por el sacristán y criados del señor cura, advirtiendo son ciertas las mañuelas que mutuamente se imputan.

Interlocutores

$\begin{array}{ll}\text { Carlos, sacristán. } & \text { Ciprián. } \\ \text { Xerpe. } & \text { Teresa. } \\ \text { Pepe. } & \text { Catuxa. }\end{array}$

Sale Carlos en su vestido acostumbrado y Xerpe, también.

Xerpe. Conque vosté, señor Calros, así foxe tan de présa para A Escabia ${ }^{61}$, sin facer caso de tantas romeiras tan guapas e tan garridas

${ }^{60} \mathrm{O}<\mathrm{o}>$ de los parece corrixir un $<\mathrm{a}>$ previo.

${ }^{61}$ Lugar de San Martińo de Fruíme, separado do núcleo parroquial por pouco máis de un quilómetro. Efectivamente, segundo recolle a súa partida de defunción, era onde vivía Carlos de Andrade. 
coma as que hoxe hay ${ }^{62}$ na festa?

Moito he, porque algún día...

Carlos. ¿ No tendrás juicio, tronera?

$<5 \mathrm{~b}>$ No me vengas con candongas,

10 que ya no estoy para ellas.

Xerpe. Mińa Virgen! Non se atufe ${ }^{63}$, teńa un pouco de pacencia, que o que lle digo non he por mal, anque lle pareza, qu'eu sempre a vosté lle quixen e lle quero, abofellas. Ora ben, séntese un pouco, que farto día lle queda para se volver á casa.

gana lo haré, que pidiendo lo están mis asentaderas, que las hallo muy pesadas, aunque están flacas y secas. Y tú siéntate también, si hemos de rascar la lengua. (Siéntanse.)

Xerpe. Fala vosté coma un santo. E agora, porque a conversa sexa algo máis divertida, de ese seu fuchique ${ }^{64}$ veña un polvińo que da pranta

\footnotetext{
${ }^{62}$ A forma hay, omitida inicialmente na copia do verso, foi restituída sobrepoñéndoa entre hoxe e na, cunha chamada no texto que indica o seu lugar preciso.

${ }^{63}$ Segundo Marcial Valladares, atufar quere dicir "amoscar; enfadar; enojar" (DdD, s. v.).

${ }^{64}$ Caixa con pequenos buracos para aspirar polo nariz o tabaco en po; tabaqueira.
} 
do pé nos arranque a frema.

$<5$ c $>$ Carlos. ¿Darte yo tabaco? ¡Gache!

Traslado al amigo de Eiras, (El estanquillero.)

35

que en el principio del mes

(si antes no le hago la cuenta)

con todo el rey en el cuerpo ${ }^{65}$

viene a rondarme a la puerta,

cuando debiéndole estoy

40

acaso treinta boletas ${ }^{66}$

y está, como mi soplillo ${ }^{67}$,

barrida mi faldriquera.

Asegúrote que al verme

en apreturas como estas

45

me da gana de arrancarme

de golpe las nariguetas

$y$, al ver entonces las de o $[\mathrm{t}] \operatorname{ros}^{68}$

de la parda frasca ${ }^{69}$ llenas,

me dan asco y me parecen,

más que narices, secretas ${ }^{70}$.

${ }^{65} \mathrm{Na}$ tradición lexicográfica da RAE documéntase a expresión Con el rey en el cuerpo a partir de 1817: "modo adverbial que comunmente se aplica al ministro que hace alarde del nombre del rey, y se excede en el uso de su autoridad" (NTLLE, s. v. rey); mais xa antes, na edición do DRAE de 1803, achamos Llevar, tener, ó traer al rey en el cuerpo: "frase con que se ostenta mando, ó superioridad afectadamente" (NTLLE, s. v. rey). Enténdese, por tanto, que o estanqueiro amosaba a súa contundencia á hora de cobrar as débedas.

${ }^{66}$ Segundo o Diccionario de autoridades da RAE (1726), "se llaman en algunas Províncias unos papelitos pequeños que se hacen y cortan, en los quales se embuelve una porción corta de tabáco, que valga un quarto" (NTLLE, s. v. boletas).

67 "Tabaquera", segundo o vocabulario de Bernardo Payzal (DdD, s. v. soplillo).

${ }^{68}$ No orixinal, oiros.

${ }^{69}$ Coa expresión parda frasca faise referencia ao tabaco. A voz frasca é un italianismo recollido polo primeiro dicionario da RAE (1732) co significado de "hojarasca y ramas pequeńas y delgadas de los árboles" (NTLLE, s. v.).

70 "Lo mismo que Necessaria, ò Letrina. Usase casi siempre en plural", segundo o Diccionario de autoridades (1739) (NTLLE, s. v. secreta). 
Predicándome a mí mismo

me digo: ¡con qué conciencia

me dejo cegar del polvo

que hasta las cachas ${ }^{71}$ me llena?;

55

¿por estas tristes narices

$<5$ d $>$ que me ha de comer la tierra?

¡Ah, narices pecadoras,

que con tan poca vergüenza

de vuestro vicio hacéis gala

60

hasta en las mismas iglesias!

¡Ah, malditas!

Xerpe. Señor Calros,

non se desespere. Teña,

que por moito que se mate

non ha de haber quen lle crea

65

que eso vay de corazón.

Dígao se non a esperenza.

(Saca la caja.)

Vaya un polviño do meu.

Carlos. Miren qué linda friolera ${ }^{72}$.

Ya se ve que lo que dije

70

no es por las cajas agenas,

que esas no me dan cuidado.

Cada pobre allá se avenga ${ }^{73}$.

¡Ola, que este es del bote!

${ }^{71}$ O DRAE de 1780 recolle a locución adverbial hasta las cachas co significado "en extremo, sobre manera" (NTLLE, s. v. cacha).

72 "Dicho ú hecho de poca importancia y que no tiene substancia, gracia ni utilidad alguna", segundo o primeiro dicionario académico do castelán (1732) (NTLLE, s. v. friolera).

73 A edición de 1780 do DRAE explica que "allá se lo avenga, ó se las avenga" é unha "frase familiar con que se dá á entender que alguno no se quiere mezclar en negocios de otro" (NTLLE, s. v. avenir). 
75

Xerpe. Pois ja se ve, que purrela ${ }^{74}$

non he para un home honrado.

Carlos. ¡Ah, bellaco! La soberbia

donde la hay no se esconde,

y si hablas de esa manera

$<6 a>$ es porque a tu pobre amo

80

los días en que le afeitas,

como la barba le rapas,

también la caja le pelas.

Pícaros hay con fortuna.

Xerpe. Ai, señor doutor, a embeja

85

nun ${ }^{75}$ home coma vosté

helle unha cousa muy fea,

e ben pudera facerse

cargo de que cando prega

coa caixa de don Francisco ${ }^{76}$, (Capellán del cura.)

90

como nela as goufas ${ }^{77}$ meta,

un adarme ${ }^{78}$ polo menos

en cada polvo lle leva.

Mais deixemos estos contos

e diga, ¿das súas eibas,

como lle vay, meu velliño?

${ }^{74}$ A voz purrela fai referencia ao vińo frouxo ou de pouca consistencia e, por extensión, pode aplicarse a calquera outro produto de mala calidade (DdD, s. v.); no texto refírese ao tabaco.

${ }^{75} \mathrm{O}$ primeiro $<\mathrm{n}>$ de nun parece corrixir un $<\mathrm{d}>$ previo.

${ }^{76}$ Francisco Prieto y Romero, capelán de San Martińo de Fruíme, onde exerceu ministerios subalternos desde a súa ordenación en 1727 ata o seu falecemento en 1779 (García Cortés 2002: 107). Aparece novamente referido nos versos 233 e 238.

77 Goufa equivale a "garra", segundo o vocabulario de Juan Manuel Pintos (DdD, s. v.).

${ }^{78}$ Antiga medida de peso que equivalía a dous gramos. 
Carlos. Amigo, de esa materia

no hay que tocarme, porque

estoy hecho una postema.

Xerpe. ¿Seique lle inchou moito a po $[\mathrm{t}] \mathrm{ra}^{79}$ ?

100

Carlos. Si así estuviesen tus muelas,

bien libres de ti estarían

las manzanas y las peras.

$<6 \mathrm{~b}>$ Xerpe. Malpocado! E as ourińas,

¿aínda, sin poder detelas,

105

se lle ensopan nas cirolas?

Carlos. ¡Oh, Dios! Esa es la miseria

que más me aflige y corrompe.

Corrómpeme las faldetas,

por delante y por detrás,

110

de las camisas más recias;

corrómpeme los gregüescos ${ }^{80}$

y los calzones de leyras ${ }^{81}$;

corrómpeme las narices

y las de mi lavandera,

115

que cuando le doy la ropa

va diciendo: "Pé, que apesta!"82,

\footnotetext{
$\overline{79}$ No manuscrito lese $<$ poira $>$, seguramente por confusión do copista entre $<\mathrm{t}>\mathrm{e}<\mathrm{i}>$. A palabra potra, segundo o dicionario de Valladares (1884), é voz "familiar" equivalente a hernia. Na tradición lexicográfica do castelán xa figura potra con este significado desde Alfonso de Palencia (1490), e na do portugués, desde Jerónimo Cardoso (1562).

${ }^{80}$ Os dicionarios académicos espańois do século XvIII indican que esta voz significa o mesmo ca calzones, isto é, a peza exterior masculina que cubría a perna desde a cintura ata o xeonllo.

${ }^{81}$ Talvez esta expresión faga referencia aos calzóns de diario, aos usados para os labores agrícolas.

${ }^{82}$ Entendemos que as palabras da lavandeira están en galego. Segundo recolle Francisco Javier Rodríguez no seu Diccionario gallego-castellano (1863), Pé!! é unha "Interjeccion con que se desaprueba una cosa por sucia, asquerosa, ruin, puerca, escandalosa, como quita allá, etc.". A mesma interxección aparece nas Décimas contra Diego Cernadas (ca. 1770): "Pè que Orellas desdichadas / cheas de tal fealdad" (Fernández Salgado 2017: 29; vid. ademais p. 175, nota 296).
} 
y quiere que a su salario le añada media peseta.

Xerpe. Que me di, siñor don Calros?

120

Que por lavalo lle levan

cartos as súas veciñas?

Se he que fan eso, pardezas,

moi pouca caridá ten.

125 dicen la han menester toda

Carlos. ¿Caridad? Esa ya ellas

para sí y aún no las llega

$<6$ c>a la suela del zapato,

pues no hay zapato ni suela.

Xerpe. E sábelle ben aínda

130

a comidiña siquera?

Carlos. Nada, amigo, para mí

ya todo me da dentera.

Ya me enfadan los guisados,

ya me amargan las cazuelas,

135

cuando otros tiempos no había

quien me ganase en lamerlas,

pues se volvían ${ }^{83}$ tan limpias

como el jaspe a la espetera.

En fin, mi Xerpe, ya toda

140

aquella grande apetencia

con que tan bien me sabían

las papas como las berzas,

ya voló, y en su lugar

me quedó una sed tan fiera

$\overline{83}$ É dicir, 'regresaban, devolvían'. 
que no sé como apagarla ${ }^{84}$,

porque el agua causa flemas

y el vino, según está,

es bebida muy aceda

y se me vuelve vinagre

150 cuando voy a hacer la cuenta.

$<6 \mathrm{~d}>$ Xerpe. Probe doutor! De esa sorte, desdichadas das botellas de meu amo cuando poida vosté á traición collerllas, que nun bíranse las manos ${ }^{85}$ llas porá de volta e media.

Carlos. Tanto como en eso, Xerpe, dices una verdad cierta, que, desde que esta sed tengo, soy como una sanguijuela que, donde pueda hallar algo que chupar, no me despegan. Conque el bueno de mi cura, como aquí no hay otra vena en que hacer otra sangría, es quien sufre la lanceta. El, como ya está escamado, bastantemente se vela $y$, cuando ve que me voy

${ }_{84}$ Polo cadro descrito, o personaxe podería padecer diabetes.

${ }^{85}$ Curiosa forma castelanizada dunha expresión plenamente galega, da que cońecemos as variantes nun virar da man (Bárdosi 2009: 42) ou no virar dunha man (Harguindey 2018). Significa 'moi rapidamente, nun abrir e pechar de ollos'. 
170

175

180

185

190

195 acercando a la alacena,

me mira con unos ojos

vivos como unas saetas

y me dice: "Mi Carlitos,

cuidado con la conciencia;

$<7$ a p para dos vasitos doite

libranza, mas, como excedas,

te juro que el primer día

que vengas, aunque te vea

echar la lengua de un palmo,

ni una lágrima ${ }^{86}$ me pruebas".

Yo, poniéndome a mirarle

medio al través, con la izquierda

agarro un vaso $y$, tomando

la botella en la derecha,

atisbando a cuando él vuelve

a otro lado la cabeza,

¡zas!, pillo un trago y después,

como que la cuenta empieza,

uno tras otro me voy

zampando los dos que restan.

Xerpe. De esas cousas non me diga,

que estou ben ó cabo delas;

e vosté ben sabe que eu,

cando talvez sirvo a mesa

póndome diante do amo

de modo que el non o vexa,

86 "Porcion pequeña, de qualquiera cosa líquida", segundo o Diccionario de autoridades (1734) (NTLLE, s. v. lagryma). 
lle fago moi bo papel.

$<7 \mathrm{~b}>$ Carlos. La Virgen te lo agradezca,

porque en beber a hurtadillas

200

un cuartillo no se peca,

como tú sabes, cuando es

la necesidad extrema.

Mas esto va largo. Adiós,

que por esta triste pierna

205

he menester todo el dia

para llegar a la aldea ${ }^{87}$.

(Hace que se va.)

Xerpe. ¿Logo hay tamén perna má?88

Carlos. Sí, que en mí no hay cosa buena.

Xerpe. Escóiteme, que parece

210 que unha foliada chega,

e por un pouquiño máis

será lástema non vela.

Carlos. Yo no estoy para esas gaitas.

(Yéndose, y Xerpe le detiene por la ropa.)

Xerpe. Pois que estea que no estea

215 non se vai aínda.

Carlos. ¡Tente!,

porque si no, la cabeza

con este palo te rompo.

Xerpe. Paus a min? Si non tivera

vergonza de pórme ás barbas ${ }^{89}$

$\overline{87}$ Ou sexa, para percorrer a escasa distancia que separa Fruíme da Escabia (véxase a nota do v. 3).

${ }^{88}$ No manuscrito, a escrita inicial do verso presenta unha orde nos seus compońentes lixeiramente diferente: “¿Logo tamen hay perna ma?”. O copista rectifica esa primeira versión riscando a forma "hay” e reescribíndoa sobreposta entre "Logo" e "tamen", cunha chamada no texto para indicar o seu lugar exacto.

${ }^{89}$ Pórse ás barbas: 'enfrontarse'. 
220

con un vello...

Carlos. ¿Qué?, ¿qué hicieras?

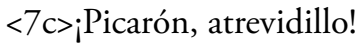

(Dale dos o tres palos.)

Xerpe. Ay de min, que me derrea!

Vosté que fai, señor Calros?

Carlos. Enseñarte a que me tengas

225

respeto.

Xerpe. Dios llo perdone,

(Sale la foliada por otra esquina y ellos se esconden.)

e agora escoite as ferreñas

e escondámonos alí

hasta ver que jeito leva.

Salen Pepe, Ciprián, Teresa (y esta con, en una cesta, la merienda) cantando las coplas siguientes:

230

1. ${ }^{\mathrm{a}}$ Miña Virgen dos Dolores,

¿quen se non vós o faría,

que fosen os vosos choros

causa da nosa alegría? Tala lala $\& .^{\text {a }}$

2. ${ }^{a}$ Pois o señor don Francisco,

¿quen o viu en outros tempos?

235

Hoxe ja non ten o probe

máis que os ósos e pelejos. Tala lala $\&{ }^{\mathrm{a}}$

3. ${ }^{\mathrm{a}}$ O probe crego de Fruíme

e mais o seu capellán

parece que o mismo leite

240

mamaron que o sacristán. Tala lala $\& .^{a}$

$<7 \mathrm{~d}>4$. $^{\mathrm{a}}$ Miña Virgen dos Dolores,

dos Dolores de Fruíme,

pois como filla vos amo, 
vós como nay asistime. Tala lala $\& .^{a}$

Pepe. Ora ben, este parece

bo canto ${ }^{90}$ para a merenda.

Ciprián. Tamén mo parece a min.

Teresa. E pois logo pouso a cesta.

Pepe. Si, que o día non dá espera.

(Siéntanse.)

E el vén algo que digamos?

Teresa. Que ha de haber? Vnha miseria,

mais entre bos compańeiros

pasará $^{91}$ seja o que seja.

Pepe. Veña para acá esa bóta,

255

porque trago as gorjas secas

de tanto cantar.

Teresa.

Axiña!

Sin comer antes? Pardezas,

que lle tragés ${ }^{92}$ boas ganas!

Ciprián. Esa nel he maña vella.

260

Teresa. Vaya pois, botad'un trago.

Pepe. Á vosa saú, Tereixa,

e de toda a compañía,

que aínda na groria vos vexa.

Teresa. Bo proveito, meu amigo.

265

$<8 a>C i p r i a ́ n$. El sóupovos ben?

Pepe.

Gorenta.

$\mathrm{E}$ a vós que vos pareceu

${ }^{90}$ Canto: 'recanto, recuncho'.

${ }^{91}$ Pasará ten aquí o significado de 'farase chegar, compartirase'.

${ }^{2}$ Tragés: 'traguedes', forma de P5 do presente de indicativo de traguer con gheada, correspondente ao tratamento de vós entre os compadres Tereixa e Pepe nesta parte do texto (véxanse os puntos 11.i e 9 do apartado de estudo lingüístico). 
do crego de Fruíme?

Ciprián. Afellas

que alá cando mozo había

de ter boa parecencia,

270

mais hoje parece ja

un cañoto da devesa.

Teresa. Malpocado! Mais con todo,

se non fose por aquela

falta de todos os dentes

275

e moas, aínda pudera

ir pasando entre os máis guapos

curas de toda esta terra,

porque a fachada he bizarra.

Pepe. Cala, muller, que en concencia

280

ja vay todo deslombado

e non rege ja a cabeza.

Ciprián. Mal por mal, posto ó seu lado,

acá para a miña idea,

o seu capellán aínda

285

val máis dous cartos na feira.

Teresa. Jesús, home, que tal dices!

E ti non lle ves siquera

os dentes negros e podres

e arrugadas as faceiras?

290

$<8$ b $>$ E que cando anda parece

leva no zapato areas?

Ciprián. Nono nego, mais tamén,

polo que contan, entre esas

eibas ten outras partidas

295

que non se achan en calquera. 
El rise de todo o mundo,

doulle Dios moita pacencia,

e, anque nunca ten un carto,

dóelle, mais non renega.

300

Pois en cantar unha misa,

según din, non ten parella

e polo gusto de oírlla

se está derretendo a cera.

Teresa. Bravo lagarto pareces!

305

E cantos anos ja leva

o cura no beneficio?

Ciprián. Oín decir que corenta

e catro justińos.

Pepe. Mama!93

Pois sendo desa maneira,

310

será home de dińeiro,

pois aforrando siquera

no ano anque non fosen

uns cen ducados, ja eran

catro mil e catrocentos.

$315<8 \mathrm{c}>$ Ciprián. Ay, home! Quen che mos dera metidos na miña bulsa!

Pepe. Vay ó cura que chos dea.

Teresa. Malpocado! Que ha de dar se anda chorando miserias e algúns seus freigueses teñen millores porcos de ceba.

${ }^{93}$ Segundo anota Juan Antonio Saco Arce na súa Gramática gallega (1868: 139), Mama! é unha interxección equivalente a "toma!" e procede do imperativo do verbo mamar. No texto trátase, sen dúbida, dunha voz paroxítona, tendo en conta as esixencias métricas do verso. 
Pepe. Con todo agora ja din

que botou a mula vella

da porta, que din que tińa

325 gran maña de tirar peras.

Ciprián. Todavía! ${ }^{94} \mathrm{Ja}$ a botou?

Farto $^{95}$ fixo, mais ¿por ela

topou quen lle dese un carto?

Pepe. Hastra seus cento e cincuenta

330 pillounos.

Ciprián. Quen cho vería

cando con tanta moeda

junta dun golpe se achou!

Pepe. Din que lles fixo unha festa

tan grande que no abroque ${ }^{96}$

335

tres netos lle derreteran ${ }^{97}$.

Mais nós estamos gastando

o tempo en estas frioleras.

Tereixa, bota máis viño.

340

Teresa. Vaya. Mais a mińa lengua

tamén he razón mollala,

e a da mińa compañeira.

${ }^{44}$ No Catálogo de voces y frases de la lengua gallega (ca. 1745-1755), o padre Sarmiento anota sobre todavía: "En Pontevedra admiración afirmativa; v. g.: dice Pedro: fulano hizo esto; admírase Juan y dice: todavía!" (DdD, s. v.).

95 Pronome indefinido co valor de 'moito'. Cf. o mesmo indefinido en función adxectiva no v. 18. Úsao igalmente María Francisca de Isla y Losada no seu Romance ao cura de Fruíme (1775): "Deixame estàr à meu cabo / layandome do meu mal, / que abo fellas farto teño" (Gondomar 2017).

${ }^{96} \mathrm{O}$ abroque ou albaroque é a bebida (e comida) que se tomaba tradicionalmente para "sancionar ou rubricar un acordo económico”. Esta práctica, que nas súas orixes abranguía todos os grupos sociais, acabou manténdose nos sectores máis populares (Castro 2010: 134-138).

${ }^{97}$ É dicir, que consumiron tres netos ou cuartillos de vińo, ou sexa, un litro e medio. 
$<8 d>$ Pepe. Pois dádenos bo despacho.

Teresa. Á boa saud'e queira

a Virgen d'oje en vinte anos

que outro con vosoutros beba.

(Bebe.)

Todos. Que bo porveito vos faga.

Teresa. Toma ti, Catuxa.

Catalina.

Veña.

A que a Virgen, que hoje aquí

nos juntou, no ceo nos vexa

(Bebe.)

da súa gracia.

350

Ciprián.

Por sempre

de todos bendita sea.

Salen Carlos y Xerpe.

Carlos. Bendígalos Dios, paisanos.

Me alegro de que tan buena

gente por acá nos honre.

355

Xerpe. Tamén a min se me alegra

o corazón de topar

con gente honrada coma esta.

Teresa. Dios se alegre con vostedes;

e pois a tal tempo chegan,

360

séntense, se son servidos

de tomar algo da tenda.

Carlos. Vsted viva muchos años,

que le estimo la fineza,

mas por las tardes a mí

ninguna comida me entra. 
$<9 a>$ Xerpe. De eso podo eu ser testigo,

mais tamén he cousa certa

que, se o convidan coa bóta,

de mil amores aceita.

370

Carlos. ¿Quién te mete a ti, bufón,

a decir esas chufletas

y en dar, sin que te lo pidan,

en mi nombre esas respuestas?

Por vida de...

375

Xerpe. Meu patrucio,

75 de min vosté non se ofenda,

que, polo que a boa fe

falei, non merezo pena.

Pepe. Vstés ${ }^{8}$ séntense, si gustan,

e déixense de requestas ${ }^{99}$;

380 pois, de que pase unha chanza entre amigos, non hay queixa.

Carlos. Es verdad. Pues sentareme

por no despreciar la oferta

(Siéntase.)

y la merced que me hacéis, mas el comer no me asienta.

Xerpe. Pois eu, ja que tanta honra

me fan, non quero perdela,

sin andar en cumprimentos,

que son cousa que me rella ${ }^{100}$.

\footnotetext{
${ }^{98}$ Sorprende esta forma castelanizada do plural do pronome de cortesía tendo en conta que en todo o texto só se rexistra o singular vosté (vs. 1, 15, 27...) e que un pouco máis arriba outro personaxe emprega o plural vostedes (v. 358).

99 Requestas: 'discusións, reproches'.

${ }^{100}$ Rellar: 'incomodar, amolar'.
} 
Teresa. Vaya un traguiño, patrón,

$<9 b>$ que aínda he da outra colleita

e non lle ha de facer mal.

Carlos. El traguito, eso sí, venga,

que hay meses que me persigue

395

una sed que me atormenta.

Brindo a la salud de ustedes.

Teresa. Dios a súa lle manteńa.

E vosté, meu mozo honrado,

para que lle corra a freba

400

non bebe tamén?

Xerpe. E logo?

Da vosa man vieiteira ${ }^{101}$,

anque non tivese gana,

eso solo ma fixera.

Teresa. Eso de no andar gastando

405

xirimońas ${ }^{102}$ me contenta

e así teño de botarllo

con cogulo ${ }^{103}$.

Xerpe. Dios lle dea

moita vida para ser

exempro das taberneiras.

${ }^{101}$ Eladio Rodríguez define o adxectivo biaiteiro como "Bienhechor, dícese de la persona que hace bien a otra u otras" e considérao sinónimo de benfeitor (DdD, s. v.). Probablemente esta definición fose elaborada a partir do exemplo extraído dunha composición de Manuel Leiras Pulpeiro publicada en 1930: “¿No'haberá un crego de man / Biaiteira, que remedio / Me día pra esa congoxa, / Que me está sempre comendo?” (TILG, s. v.). Só cońecemos outro exemplo máis de uso literario deste adxectivo, nun contexto idéntico ao que estamos a comentar; aparece no Entremés ao feliz e real parto da nosa raiña (1707): "Da vosa mao bieiteyra / beberey, brindo por todos" (Gondomar 2017).

${ }^{102}$ Variante popular de cerimonias. O padre Sarmiento emprega cirimoñas no Coloquio de 24 galegos rústicos (véxase no TILG, s. v. cerimonia).

${ }^{103}$ Con cogulo: 'a rebordar'. Cf. a cugulo nas Papeletas do padre Sobreira ou no Diccionario enciclopédico de Eladio Rodríguez (DdD, s. v.). 
Á saú do mayordomo,

que correu hoje coa festa.

Casouse inda hay poucos días

counha moza frescacheira,

moi honrada e moi capaz,

415

mais váisenos desta terra

e hemos de topalo menos.

$<9$ c $>$ Mais, pois lle ten convenencia,

esta Virgen dos Dolores

vaya con el e con ela.

420

Pepe. Vaya e tanto ben lle faga

que en tod'as cousas florezan.

Ciprián. Eu, a este patrón, parece,

se non me enganan as señas,

que o estou ińorando.

Xerpe. Boa!

425

Pois quen en eso tropeza?

É verdá que, como agora

no está vestido da veca ${ }^{104}$,

do seu roquete ${ }^{105}$ de encaijes ${ }^{106}$

e a súa sotana negra,

430

que lle fai cando a ten posta

mercede en taparlle as pernas,

non he moito non caer

en quen he, así á primeira

vista. Pois sepa vosté

${ }^{104}$ Beca: 'Especie de manto que usaban sobre a sotana os eclesiásticos que gozaban dalgunha dignidade' (DRAG, s. v.).

${ }^{105}$ Roquete: 'Sobrepeliz estreita e con mangas curtas que usan os bispos e outras dignidades eclesiásticas'. (DRAG, s. v.).

${ }^{106} \mathrm{O}<\mathrm{j}>$ de encaijes semella corrixir un $<\mathrm{g}>$ escrito previamente. 
que esta cara reverenda

élle mesmamente a misma,

desde o queixo hastra a moleira,

do señor Calros de Andrade

Soutomayor y outras herbas,

440

por outro nome, o doutor

ou, porque máis beno entendan,

o famoso sancristán

$<9$ d > de Fruíme.

Ciprián. Enhorabuena ${ }^{107}$

vaiche, que así che me folgo,

445 que che me cadra de pelras.

Conque vosté he o señor Calros?

Carlos. Para lo que se le ofrezca

mandarme.

Ciprián. Véncheme a promo ${ }^{108}$

a sorte. Pois vosté sepa

450

que me acordo de que hay anos,

noutra función coma esta,

lle oín decir a vosté,

con voz ben crara e desperta,

unhas copras moi bonitas

455

con que a esta Sobrana Reina

dos Dolores alababa;

e tanto gusto con elas

tiven que agora estimara

que a repetilas volvera,

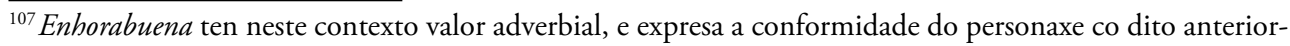
mente.

${ }^{108}$ Expresión tomada do castelán. O DRAE recolle o significado "a punto, con oportunidad, al pelo" para a locución a plomo (desde a súa décimo oitava edición, de 1956) (NTLLE, s. v. plomo). 
460

para consolarme a alma.

Carlos. Eso, amigo, quiere flema

y ahora se me hace tarde;

fuera de que la experiencia

nos enseña que las cosas

465

repetidas son molestas.

Ciprián. Jesús! Neso non se pare

porque, cando se endereitan

para alabanza da Virgen,

todos de oílas se alegran.

470

$<10$ a $>$ Anímese e bote un trago.

Carlos. Eso sí que me hace fuerza,

pues para la tentación

de un trago no hay resistencia.

(Bebe.)

Súpome como un almíbar.

475

Dios delante ${ }^{109}$, va de arenga.

Levántase y canta algunas que sabe y, acabadas, dice Ciprián.

Ciprián. Vítor ó señor don Calros,

vítor. E agora Tereixa

vaya recollendo os lotes,

que he tempo d'ir para a aldea.

480

Teresa. Tan ajiña? E non será

razón facerlle unha festa

primeiro ó señor don Calros,

co pandeiro e coas ferreñas,

109 “Con la ayuda de Dios”, segundo a quinta edición do DRAE (1817) (NTLLE, s. v. Dios). A expresión aparece rexistrada no dicionario de Valladares como Dios diante (DdD, s. v. diante). O seu uso aínda é moi común no galego das terras de Lousame e Noia. 
485

e supricarlle que baile

connosco unha muiñeira?

(Tocan.)

Xerpe. Pardez, que tendes razón, ben aja a vosa avelencia.

Ea, váyase animando, meu doutor, a dar ás pernas,

490 que aquí están as castañolas.

(Tocan.)

Carlos. ¿Qué dices, loco? ¿Qué intentas?

Bueno estoy yo para danzas.

Pepe. Ha de ser anque non queira.

Teresa. Non se faga de rogar,

495 señor Calros, ande, veña, $<10$ b $>$ que eu bailarei con vosté.

(Tirándole de la capa.)

Carlos. Muger del diablo, ¿qué piensas?

¿Tentar a este pobre viejo? ¿Hacer yo cosa tan fea?

500

Teresa. Ande, señor Calros, ande, que aínda non lle so tan vella.

Xerpe. Dispóñase e bote fóra o balandrán ${ }^{110}$, si lle pesa. (Quiere desnudarle el casacón.)

Pepe. Vamos, señor Calros, vamos.

Carlos. ¿Qué hacéis, maldita caterva ${ }^{111}$ de demonios? ¡Esto es ya muchísima desvergüenza

(Dale a todos de palos.)

\footnotetext{
${ }^{110}$ Segundo o primeiro dicionario da RAG, "vestidura talar que usan los eclesiásticos, ancha, desceñida, con esclavina y mangas perdidas" (DdD, s. v.).

${ }^{111}$ Despois de caterva distínguese un signo de interrogación final riscado.
} 
Todos. Ay!, ay!

Carlos. conmigo! ¡Bellacos, fuera!

$510 \quad$ Teresa. Ay que me descostillou!

Xerpe. A Virgen nos favoreza.

Carlos. Eso es lo que yo quiero,

que con las mayores veras

y la devoción más fina,

515

digamos a boca llena:

en la muerte y en la vida

la Virgen nos favorezca.

Amén. 


\section{REFERENCIAS BIBLIOGRÁFICAS}

Album = [Antonio M. ${ }^{a}$ De LA Iglesia (ed.)] (1862): Album de la caridad. Juegos florales de la Coruña en 1861, seguido de un mosaico poético de nuestros vates gallegos contemporáneos. Coruńa: Imprenta del Hospicio provincial á cargo de D. Mariano M. y Sancho. <http://biblioteca.galiciana.gal/gl/consulta/registro. cmd?id $=5195>$.

ALGa 1 = Instituto da Lingua Galega (1990): Atlas lingüistico galego. Vol. 1: Morfoloxía verbal. 2 vols. A Coruña: Fundación Pedro Barrié de la Maza.

Álvarez, Rosario (2018): «Galanteo de mozo e moza, romance en lingua galega (séc. XVIII). Edición e estudo", Madrygal. Revista de Estudios Gallegos 21, 15-31. <https://doi.org/10.5209/MADR.62591>.

Álvarez, Rosario / Francisco Millán Rodríguez (2016): «O 'Pranto da frota, por unha ninfa galega' (c. 1702). Tradición manuscrita, autoría, edición e estudo», Cuadernos de Estudios del Siglo XVIII 26, 233-270. <https://doi.org/10.17811/cesxviii.26.2016.233-270>.

BÁrdosi, Vilmos (2009): "Os perfís lingüísticos da man en francés, contrastados co húngaro, español, galego e alemán", Cadernos de Fraseoloxía Galega 11, 17-47. <http://www.cirp.es/pub/docs/cfg/cfg11.pdf>.

Basanta Campos, José Luis (coord.) (2002): Marcas de agua en documentos de los archivos de Galicia. Siglo XIX. Tomo VII. [A Coruña]: Fundación Pedro Barrié de la Maza.

Buezo, Catalina / Nuria Plaza Carrero (2008): «Tipología de las formas breves», en Javier Huerta Calvo (dir.): Historia del teatro breve en España. Madrid / Frankfurt am Main: Iberoamericana / Vervuert, 63-119. <https://doi.org/10.31819/9783964563491-003>.

CAG = Ana Isabel Boullón Agrelo / Xulio Sousa Fernández (dirs.): Cartografía dos apelidos de Galicia . Santiago de Compostela: Instituto da Lingua Galega. <http://ilg.usc.es/cag/>.

Carballo Calero, R[icardo] (1978): «Testemunhos gráficos do galego decer 'dizer'», Verba. Anuario Galego de Filoloxía 5, 101-112.

Castro, Xavier (2010): A rosa do viño. Cultura do viño en Galicia. Vigo: Galaxia.

Cernadas y Castro = Piscator de Fruime (1762): El Cura y el Sacristan. Kalendario doloroso. Diario de quartos de luna, con los sucessos elementales, y misteriosos para este año de 1762. Madrid: Imprenta de D. Gabrièl Ramirez. <http://bdh-rd.bne.es/viewer.vm?id=0000041228\&page=1>.

DAG = Ana Isabel Boullón Agrelo (coord.): Dicionario dos apelidos galegos. [En preparación].

DdD = Antón Santamarina (coord.): Dicionario de dicionarios. Corpus lexicográfico da lingua galega. Vigo / Santiago de Compostela: Seminario de Lingüística Informática-Grupo TALG / Instituto da Lingua Galega. <http://sli.uvigo.es/DdD/>.

DRAG = Manuel GonzÁlez GonzÁlez (dir.): Dicionario da Real Academia Galega. A Coruña: RAG. $<$ https://academia.gal/dicionario $>$.

Fernández Salgado, Xosé A[ntonio] (2017): Cincuenta décimas contra don Diego Zernadas. Edición e estudo dun novo texto en galego do século XVIII. Santiago de Compostela: Edicións Laiovento.

Freixeiro Mato, Xosé Ramón / Xosé Manuel Sánchez Rei / Goretti Sanmartín Rei (2005): A lingua literaria galega no século XIX. A Coruña: Universidade da Coruña.

García Cortés, Carlos (2002): O cura de Fruime. Diego Antonio Cernadas e Castro (1702-1777). Recuperación biográfica. Catalogación da obra publicada. Antoloxía poética galega. Santiago de Compostela: Instituto Teolóxico Compostelano. 
Gayoso Carreira, Gonzalo (1965): «La fabricación del papel en Galicia del siglo XviII a nuestros días», Investigación y Técnica del Papel 4, 193-223.

Giraldo, Joseph Antonio (1766): Historico legal informe que para manifestacion de artificios humanos, i para escarmiento de parricidas escrivia el Lic. D. Joseph Antonio Giraldo. Santiago: Imprenta de Ignacio Aguayo i Aldemunde. <https://minerva.usc.es/xmlui/handle/10347/8103>.

Gondomar = Rosario Álvarez / Ernesto González Seodne (eds.) (2017): Gondomar. Corpus dixital de textos galegos da Idade Moderna. Santiago de Compostela: Instituto da Lingua Galega. <http://ilg.usc.gal/ gondomar/>.

González Montañés, Julio I[gnacio] (2002-2009): Teatro y Espectáculos Públicos en Galicia. De los orígenes a 1750. <http://www.teatroengalicia.es>.

Harguindey, Henrique (2018): «De ollo», Sermos Galiza (15.6.2018). <https://www.sermosgaliza.gal/articulo/lingua/ollo-henrique-harguindey/20180615134309069819.html>.

IgLesia, Antonio de la (1886): El idioma gallego. Su antigüedad y vida. Tomo I. La Coruña: Latorre y Martinez, Editores. <http://biblioteca.galiciana.gal/gl/consulta/registro.do?control=BDG20110013103>

IgLesia, Antonio de la (1888): «Ortografía gallega», Galicia Humoristica, I, 10 (30/05/1888), 305-307; I, 11 (15/06/1888), 337-339; II, 1 (15/07/1888), 13-15.

Langlet, Abate J[uan] (1763): «[Recensión de La Débora victoriosa, y la triunfante Jahèl]», El Hablador Juicioso, y Critico Imparcial. Noticias Literarias de España, Acompañadas de Reflexiones Criticas, y Eruditas 6, 28-32. <http://teatroengalicia.es/datateatro/anexos/fruime2.pdf>.

MARIÑo PAZ, Ramón (2003): O idioma galego no limiar da súa renacenza. Estudo lingüístico de textos pregaleguistas. Monografía 2 da Revista Galega de Filoloxía. A Coruña: Universidade da Coruña.

Mariño Paz, Ramón (2007): «Edición e estudo lingüístico do romance de María Francisca de Isla y Losada ao cura de Fruíme (ca. 1774-1777)», Revista Galega de Filoloxía 8, 57-98.

Mariño Paz, Ramón (2008): Historia de la lengua gallega. München: Lincom GmbH.

Mariño Paz, Ramón (2012): "Análise lingüística da obra en galego de Antonio Benito Fandiño», en Ramón Mariño Paz (ed.): Papés d'emprenta condenada (II). Lingua galega e comunicación nos inicios da Idade Contemporánea. Santiago de Compostela: Consello da Cultura Galega / Instituto da Lingua Galega, 317-384. <http://consellodacultura.gal/publicacion.php?id=1541>.

Mariño Paz, Ramón (2014): "A carta en galego de Magdalena García de Ogando a Martín Sarmiento. Edición interpretativa e breve comentario lingüístico", Madrygal. Revista de Estudios Gallegos 17, 67-79. <https://doi.org/10.5209/rev_MADR.2014.v17.45739>.

Mariño Paz, Ramón (2017): Fonética e fonoloxía históricas da lingua galega. Vigo: Edicións Xerais de Galicia.

Mariño Paz, Ramón (2019): «O cambio dizes > dis, diz > di, dizen > din nas fontes do galego medio», en Xosé Antonio Fernández Salgado / Aquilino Alonso Núñez (eds.): Non haberá illa, pro hai o nome. Homenaxe a Antón Palacio Sánchez. Vigo: Universidade de Vigo, 97-113.

Monteagudo, Henrique (2005): «A xeneralización do uso do grafema $<\mathrm{x}>$ para a consoante $/ \mathrm{f} /$ na escrita galega. Notas sobre a súa orixe (ss. XVI-XVIII)», en Ana Isabel Boullón Agrelo / Xosé Luís Couceiro Pérez / Francisco Fernández Rei (eds.): As tebras alumeadas. Estudos filolóxicos ofrecidos en homenaxe a Ramón Lorenzo. Santiago de Compostela: USC, 405-421.

Murguía, M[anuel] (1917): «Don José Cornide y sus versos en gallego», BRAG 114, 162-169; 115, 179-182. 
NTLLE = RAE: Nuevo tesoro lexicográfico de la lengua española. Madrid: RAE. <http://ntlle.rae.es/ntlle/ SrvltGUILoginNtlle>.

Obras = Diego Antonio Cernadas y CASTRo (1778-1781): Obras en prosa y verso del Cura de Fruime. Madrid: D. Joachin Ibarra, Impresor de Cámara de S. M. Tomos I e II: 1778, tomos III e IV: 1779, tomos V e VI: 1780 e tomo VII: 1781. <https://minerva.usc.es/xmlui/handle/10347/9185>.

Pardo de Neyra, Xulio (2002): O labor lírico do ilustrado cura de Fruime. Textos galegos de Zernadas y Castro. Santiago de Compostela: Edicións Laiovento.

Pardo Gómez, María Virtudes (1998): Catálogo de manuscritos da Biblioteca Xeral. Santiago de Compostela: USC.

Peinado López, María Rita (1972): Textos inéditos del primer cura de Fruime don Diego Antonio Cernadas y Castro y otros relacionados con los mismos. Tese de licenciatura inédita lida na USC.

Piñeiro, Alberto (2008): «O culto a San Ramón en Bealo», La Voz de Galicia (26.9.2008). <https://www. lavozdegalicia.es/noticia/barbanza/2008/09/26/culto-san-ramon-bealo/0003_7171613.htm>.

Rey Castelao, Ofelia (1998): «Producción impresa y promoción eclesiástica en la Galicia de fines del Antigo Régimen", Semata. Ciencias Sociais e Humanidades 10, 281-319.

SACo Arce, Juan A[ntonio] (1868): Gramática gallega. Lugo: Imprenta de Soto Freire. <http://biblioteca. galiciana.gal/gl/consulta/registro.cmd?id=4866>.

Sacristan de Fruime, El (1779): Quien possee no pleytee. Santiago: Imprenta de Sebastian Montero y Frayz. <http://bdh-rd.bne.es/viewer.vm?id=0000089118\&page $=1>$.

TILG = Antón Santamarina (dir.) / Ernesto González Seoane / María Álvarez de la Granja: Tesouro Informatizado da Lingua Galega (Versión 4.0). Santiago de Compostela: Instituto da Lingua Galega. $<$ http://ilg.usc.es/TILG/>.

TMILG = Xavier VArela Barreiro (dir.) (2004-): Tesouro Medieval Informatizado da Lingua Galega. Santiago de Compostela: Instituto da Lingua Galega. <http://ilg.usc.es/tmilg>.

Varela Barreiro, Xavier (2015a): «Achegas recentes á cronoloxía do alomorfo nasal do clítico CD de 3.a persoa», en Francisco Dubert García / Gabriel Rei-Doval / Xulio Sousa (eds.): En memoria de tanto milagre. Estudos dedicados ó profesor David Mackenzie. Santiago de Compostela: USC, 213-224.

VArela Barreiro, Xavier (2015b): «Freguesía e parroquia. Dúas voces que reclaman un dicionario histórico para a lingua galega», en Ramón Mariño Paz / Xavier VArela Barreiro (eds.): Lingüística histórica e edición de textos galegos medievais. Anexo 73 de Verba (Anuario Galego de Filoloxía). Santiago de Compostela: USC, 147-175. 


\section{ANEXO}

\section{Partida de defunción de Carlos de Andrade. Transcrición e reprodución fotográfica}

[Arquivo Histórico Diocesano de Santiago de Compostela. P011563, Fruíme, San Martińo. Serie: Libros Sacramentales, Difuntos (1753-1843), folio 123r]

En treinta de Marzo delaño de mil setecien/(cien)tos setenta y nueve se murio D. ${ }^{\mathrm{n}}$ Car/ los Antonio de Andrade viudo que fuè / de Francisca da Figueira vecinos del Lug. ${ }^{\text {/ de }}$ la Escabia de esta Feligresia: Recibio los / Santos Sacramentos. Sepultose enla Capi/ llade Nuestra Señora delos Dolores inclu/sa enesta Parroquial Yglesia: Hizo tes/tamento, nodejò obra pia. $\mathrm{y}$ para que $/$ conste lo firmo $=$ Antonio Fran. ${ }^{\mathrm{co}}$ de Castro [Rubricado]

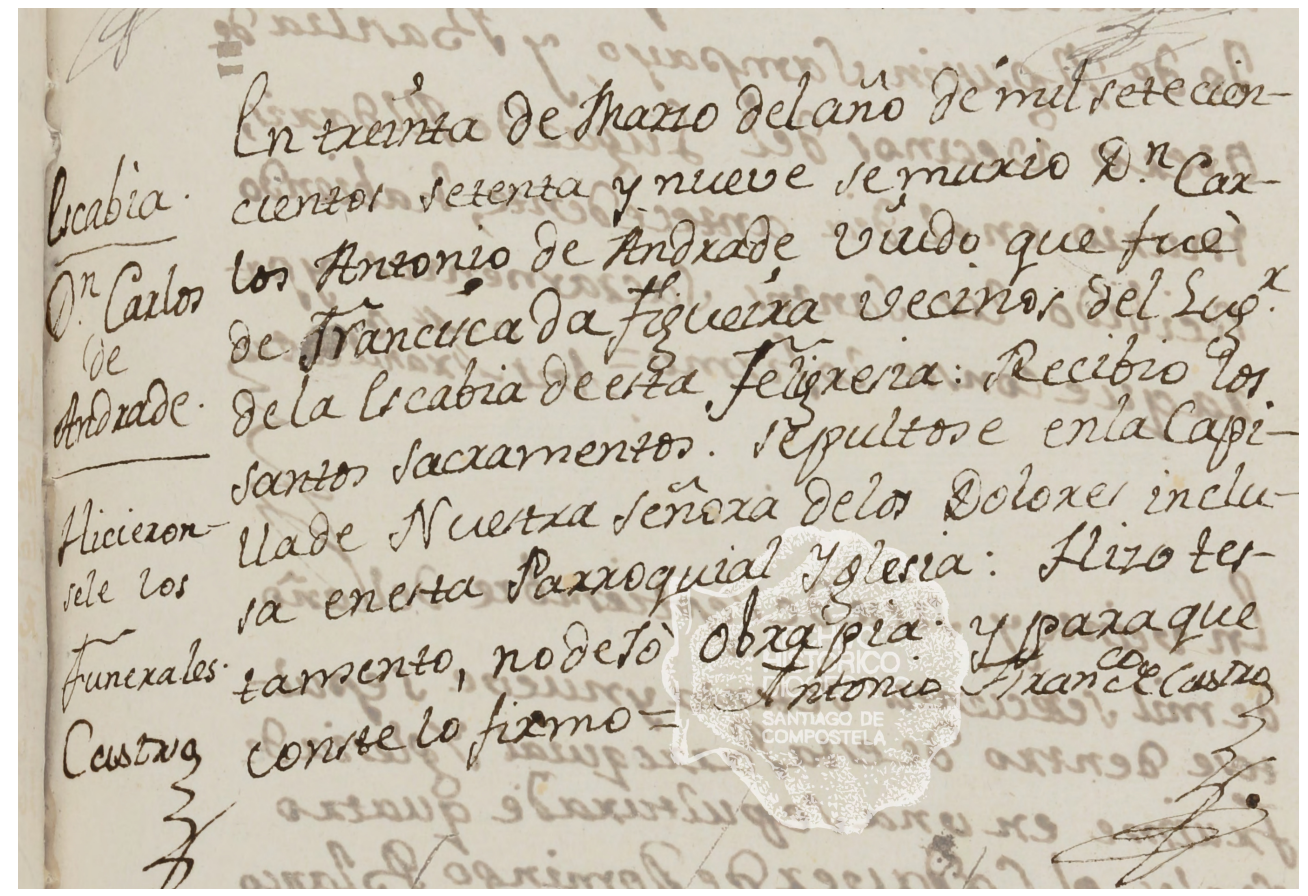

(C) Arcebispado de Santiago de Compostela 